$1-1-1968$

\title{
An input-output analysis of the upper South Branch Valley of West Virginia
}

Nelson L. Bills

Alfred L. Barr

Follow this and additional works at: https://researchrepository.wvu.edu/ wv_agricultural_and_forestry_experiment_station_bulletins

\section{Digital Commons Citation}

Bills, Nelson L. and Barr, Alfred L., "An input-output analysis of the upper South Branch Valley of West Virginia" (1968). West Virginia Agricultural and Forestry Experiment Station Bulletins. 568T.

https://researchrepository.wvu.edu/wv_agricultural_and_forestry_experiment_station_bulletins/679 @ WVU. It has been accepted for inclusion in West Virginia Agricultural and Forestry Experiment Station Bulletins by an authorized administrator of The Research Repository @ WVU. For more information, please contact ian.harmon@mail.wvu.edu. 
West Virginia University Libraries

308021004938289 


\section{Digitized by the Internet Archive in 2010 with funding from Lyrasis Members and Sloan Foundation}




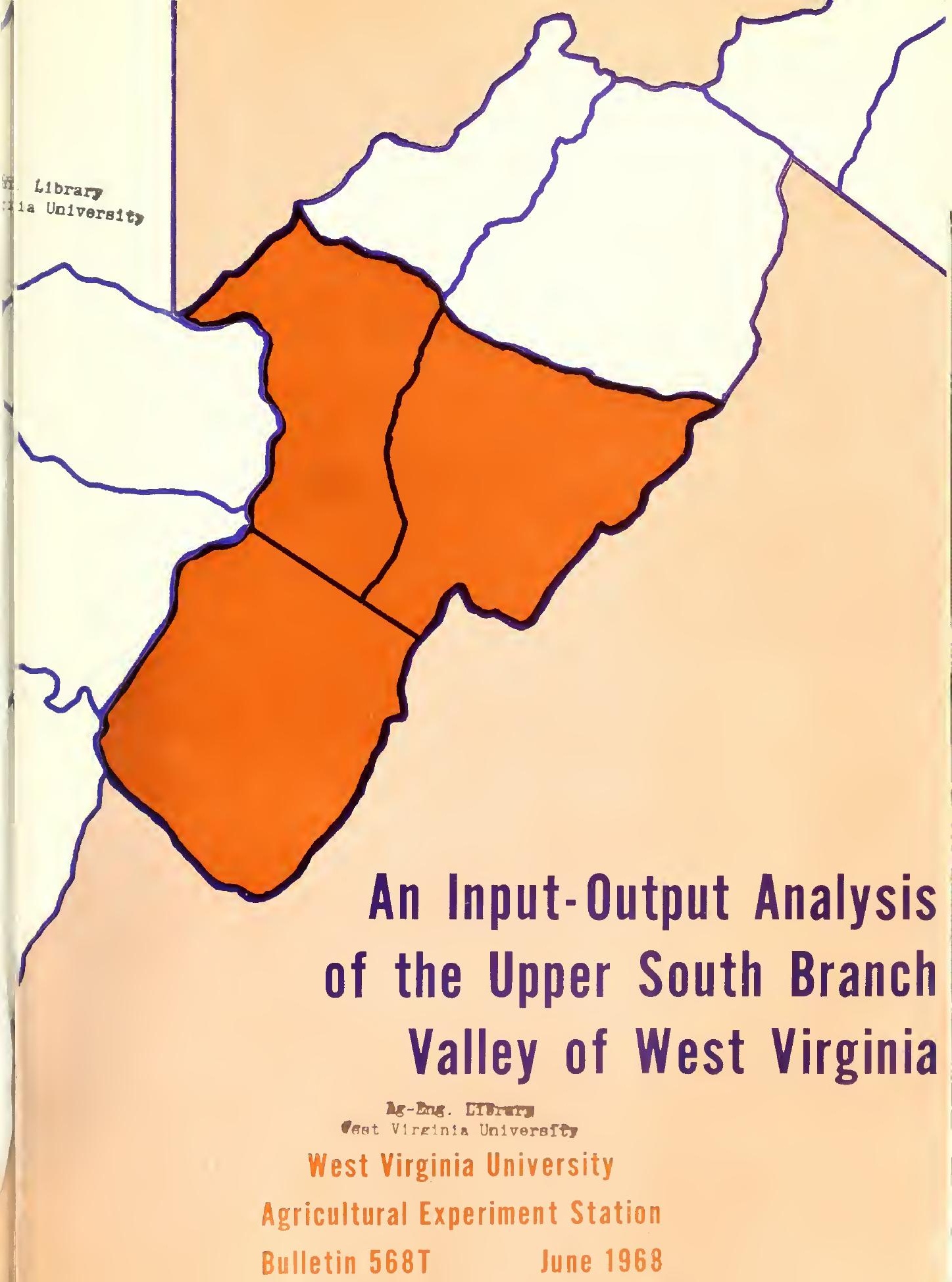




\section{The Authors}

Nelson L. Bills was a Research Assistant, Department of Agricultural Economics, at the time of this study. He is now an Agricultural Economist with the U.S.D.A. Economic Research Service, Washington State University, Pullman, Washington.

Alfred L. Barr is Associate Agricultural Economist.

\section{Acknowledgments}

The author's gratefully acknowledge the assistance of Dr. Robert I. Coltrane of the Economic Research Service, U.S.D.A., in the preparation of this manuscript. Also, the authors acknowledge the assistance of county agricultural workers, farmers, and other firm managers who assisted in the collection of clata for this study; Dr. James L. Stallings who assisted in planning of the study; and Dr. John Chapman who assistcd in developing the analytical procedurc.

This study was partially financed by a grant from the Appalachian Rcgional Commission issued through the Cooperative State Research Service (Grant No. 508-15-7). 


\section{AN INPUT-OUTPUT ANALYSIS \\ OF THE UPPER SOUTH BRANCH VALLEY \\ OF WEST VIRGINIA}

Nelson L. Bills and Alfred L. Barr

West Virginia University

Agricultural Experiment Station

A. H. VanLandingham, Director

MORGANTOWN

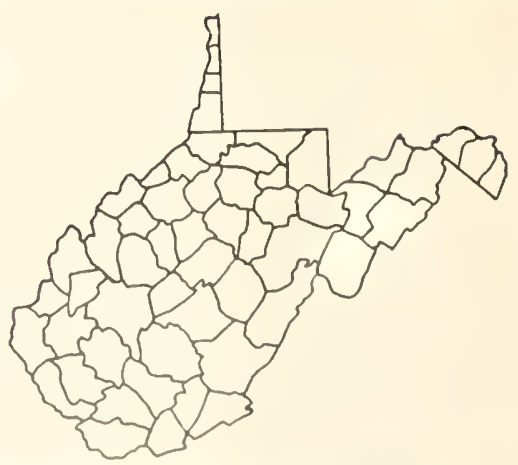




\section{Contents}

SUMMARY … . . 3

Introduction ............ . 5

The Study Area ....................... ... 5

Population of the Area ............... . 6

Labor Force of the Area .....

Methodology Used .............................. 9

The Transaction Toble .... .............. 9

Technical Coefficients ...... ........... 12

Assumptions of Input-Output Analysis ................ 12

Advantages of Input-Output Analysis .............. 12

Lımitations .......................... 13

Valuotion of Outputs and Inputs ............ 13

Copital Transactions ....................... 13

The Upper South Branch Transactions Table . . . . . . . . . . . . 13

Data Collection .......................... 15

Matrix Canstruction ........................ 16

Analysis of the Local Economy ..................... 16

Structural Interdependence .................... 19

Direct Requirements or Technical Coefficient Matrix ........... 20

Intcrdependency Coefficients ..................... 20

Input-Output Multipliers ..................... 24

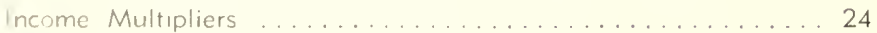

Employment Multipliers ....................... 28

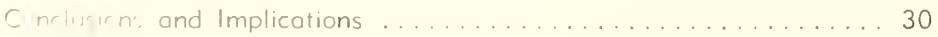

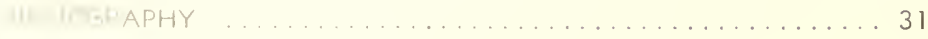




\section{Summary}

The objective of this study was to determine the economic contribution of different types of industries within a region and to determine the effects of an expansion or contraction of specific types of industry within a local community on income and employment.

The area included in the study was the Upper Soutl Branch Valley (Grant, Hardy, and Pendleton counties) of West Virginia. The entire area was classified as rural, and over 40 per cent was classified rural-farm by the 1960 Census of Population. The three-county area had significant changes in the industrial composition of its labor force between 1950 and 1960. The per cent of the total labor force employed in agriculture declined from 49 per cent in 1950 to 31 per cent in 1960. Employment in other sectors of the local economy increased but not enough to offset these decreases. Total population for the three counties declined by 8.5 per cent and the size of the labor force declined by 10.9 per cent between 1950 and 1960.

Monetary transactions between 14 endogenous processing sectors were estimated for 1965. Deliveries (sales) to final clemand, including local household consumption, capital formation, and exports, were determined for each endogenous sector. Purchases in excess of local interindustry transactions were allocated to the final payments sectors of the transactions table which included local household payments, depreciation allowances, and import payments.

The regional transactions table was computed from data obtained from primary and secondary sources. Data for 12 or 14 processing sectors were obtained by a field survey. A group survey was used to supplement data for the agricultural sector and secondary sources of information were used to meet other data requirements.

The processing quadrant of the transactions table was used to determine the impact of a change in final demand on local income and employment for each processing sector. The direct relationship between total gross output and input purchases was estimated for each processing sector. Indirect and induced requirements were estimated to determine the generative effect associated with a unit cluange in deliveries to final demand by each sector:

Type I income multipliers were computed for cach processing sector. A Type I multiplier is the ratio of direct to the sum of direct and indirect changes in household income. These multipliers were used to estimate payments which directly and indirectly acerne to local houscholds as a result of a unit change in direct houschold payments in each processing sector.

Type II income multipliers were also computed for each processing sector of the local economy. The Type II multiplier is the ratio of direct to the sum of direct, indirect, and induced changes in household income. The induced component is an estimale of payments to local houseloolds which result from adjustments required to meet changes in each sector's household consumption demand. 
Dollal transactions between processing sectors were converted to employment equivalents for the purpose of deriving employment multipliers. Type 1 (the ratio of direct to the sum of direct and indirect employment) and Type II (the ratio of direct to the sum or direct, indirect, and induced employment requirements) employment multipliers were computed.

Variation in the degree of interindustry dependency was reflected in the relative sizes of the incone multipliers. Agriculture, food manufacturing, communications and utilities, and wholesale and retail trade exhibited relatively strong interindustry linkages. Weak interindustry linkages, i.e., low income multipliers, were observed in the wood manufacturing, services, commercial banking, other finance, insurance, and realestate sectors. 


\section{AN INPUT-OUTPUT ANALYSIS OF THE UPPER SOUTH BRANCH VALLEY OF WEST VIRGINIA}

\section{Nelson L. Bills and Alfred L. Barr}

D ECREASES IN POPULATION, employment opportunities and income in rural areas in West Virginia are of major concern to a number of public and private groups. In efforts to increase present funds and stimulate employment and income growth, considerable time and resources are being expended by groups at the local, state, and Federal level.

Efforts to increase local income and employment are often hampered by insufficient information about the economic structure of a region. There is a need to determine the economic contribution of different types of industries within a region and to determine the effects of an expansion or contraction of specific types of industry within the local community on income and employment.

A study was initiated at the West Virginia Agricultural Experiment Station to analyze the economic structure of the Upper South Branch
Valley, including Grant, Hardy, and Pendleton counties in West Virginia. This bulletin represents the second and final report on the results of this research project.'

\section{The Study Area}

The Upper South Branch Valley of eastern West Virginia was selected for this study because agriculture is relatively important to the economy of the area; in 1964, over 29 per cent of the total personal income in the three counties was derived from the sale of farm products. Moreover, the socio-economic characteristics of the three-county area are relatively homogeneous. The study area, encompassing 1,757 square miles, contained a population of 25,705, or 1.38 per cent of the State total (Table 1), in 1960. There were 14.6 inhabitants per square mile, compared with 77.3 per square mile for the State.

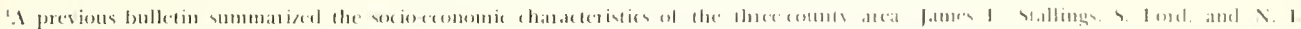

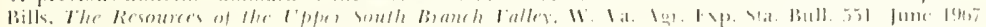

TALISE 1

Total Population of the United States, West Virginial and the Upper South liranclo Valley, 1930-600

$\begin{array}{lr}\text { Area } & \mathbf{1 9 3 0} \\ \text { ates } & \mathbf{( 0 0 0 )} \\ \text { inia } & 122,775.0 \\ \text { ath Branch Valley } & 1,729.2 \\ \text { County } & 27.9 \\ \text { County } & 8.4 \\ \text { eton County } & 9.8 \\ \end{array}$

19.10

$(000)$

131.669 .0

1.901 .9

30.5

8.8

10.8

10.8
1950

(000)

$150,679.0$

$2,005.5$

28.1

8.7

10.0

9.3
1960

(000)

179.323 .0

$1,860.4$

25.7

8.3

9.3

8.0

"Source: L. S. consus of Population, 1930-60. 
The topography of the Upper South Branch Valley is highly variable. Elevations range from 725 feet to 4,860 feet. The relief of the area is gencrally rough but is characterized by relatively narrow flat valleys along rivers. Approximately 70 per cent of the total land area is in forest and over 15 per cent is federally owned (Table 2). Most of the federally-owned land in the threecounty area is in the Monongahela and George Washington National forests. In 1958, 25.7 per cent of the total area was in cropland and pasture. According to the 1964 Census of Agriculture, approximately 57 per cent $(640,700$ acres) was in farms.

\section{POPLLATION OF THE AREA}

In 1960 , the entire population of the area was classified as rural non-farm and rural farm
(Table 3), as all five incorporated places in the area had fewer than 2,500 inhabitants each. These five places contained almost 20 per cent of the total residents in 1960 (Table 4). The area has been subject to a declining population for the past two decades. From 1950 to 1960 , population declined by 8.5 per cent in the threecounty area while the population of the State declined 7.2 per cent (Table 6 ).

The Upper South Branch Valley has experienced out-migration during the past decade, the trend resembling that of the entire State during the period. Table 5 shows estimates of net migration by age group for the State and for each of the three study counties from 1950 to 1960. These data are defined as an estimate of net migration in that no information is available on total in-and-out-movements of population

TAIBLE ?

Major Uses of Land in West Virginia and the Upper South Branch Valley, 1958

\begin{tabular}{|c|c|c|c|c|}
\hline \multirow[b]{2}{*}{ Major Ise } & \multicolumn{2}{|c|}{ West Virginial } & \multicolumn{2}{|c|}{ Upper South Branch Valley } \\
\hline & $\begin{array}{l}\text { Acres } \\
(000)\end{array}$ & Per Cent & $\begin{array}{r}\text { Acres } \\
(000)\end{array}$ & Per Cent \\
\hline Cropland & $1,521.1$ & 9.9 & 79.8 & 7.1 \\
\hline Pasture & $2,572.8$ & 16.7 & 207.8 & 18.6 \\
\hline Forest & $9,465.2$ & 61.4 & 655.0 & 58.3 \\
\hline Federal & 935.0 & 6.1 & 170.1 & 15.1 \\
\hline Urban & 433.2 & 2.8 & 3.4 & 0.3 \\
\hline All Other & 483.2 & 3.1 & 7.0 & 0.6 \\
\hline TOTAL LAND AREA & $15,410.3$ & 100.0 & $1,124.0$ & 100.0 \\
\hline
\end{tabular}

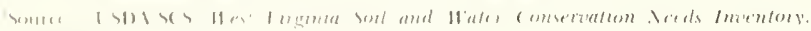

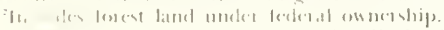

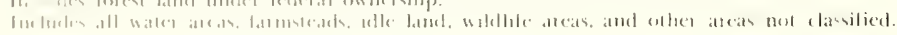

TAIBLE 3

Vrban, Rural Non-Farm, and Rural Farm Population: United States, West Virginia, and the Upper South Branch Valley, 1960'

\begin{abstract}
United
States
\end{abstract}

69.9

22.6

7.5

100.0
West
Virginia

I'er Cent

18.0

60.4

21.6

100.0

\section{Upper Soutli \\ Branch Valley}

0.0

59.4

40.6

100.0 
TABLE 4

Population of Ineorporated Places in the Upper South Branch Valley, 1960

Item

Total Population

Incorporated Places

Bayard

Petersburg

Moorefield

Wardensville

Franklin
County

Grant

Grant

Hardy

Hardy

Pendieton
Population

Total

25,705

5.044

484

2,079

1,434

289

758
Per Cent of Total

100.0

19.6

1.9

8.1

5.6

1.1

2.9

'Source: L'. T. Cemsu of Population. I960.

TABLE 5

Estimated Net Migration Rate by Age Groups; West Virginia, Grant, Hardy, and Pendleton Counties, 1950-60

\begin{tabular}{|c|c|c|c|c|}
\hline \multirow[b]{2}{*}{ Age Group } & \multicolumn{4}{|c|}{ Per Cent of 1950 Population } \\
\hline & W. Va. & Grant & Ilardy & Pendleton \\
\hline All ages & -19.3 & -17.9 & -17.2 & -22.0 \\
\hline 0 & -7.1 & -6.7 & -4.3 & +0.4 \\
\hline $5-9$ & -15.4 & -16.0 & -4.3 & -100 \\
\hline $10-14$ & -17.0 & -18.2 & -13.2 & -15.7 \\
\hline $15-19$ & -22.8 & -25.5 & -27.3 & -27.7 \\
\hline $20-24$ & -42.9 & -47.6 & -49.0 & -56.6 \\
\hline $25-29$ & -39.3 & -40.3 & -45.6 & -54.9 \\
\hline $30-34$ & -27.0 & -26.4 & -19.5 & -29.6 \\
\hline $35-39$ & -22.4 & -20.8 & -17.0 & -20.9 \\
\hline $40-44$ & -17.2 & -10.9 & -9.0 & -15.8 \\
\hline $45-49$ & -14.2 & -3.7 & -15.5 & -14.6 \\
\hline $50-54$ & -12.1 & -5.4 & $\begin{array}{r}-5.1 \\
-\end{array}$ & -8.3 \\
\hline $55-59$ & -11.0 & -4.7 & -3.1 & -140 \\
\hline $60--64$ & -7.0 & -0.0 & -7.8 & -8.6 \\
\hline $65-69$ & -7.0 & -9.2 & -4.9 & -10.0 \\
\hline $70-74$ & -4.5 & -0.3 & -3.6 & -7.7 \\
\hline $75+$ & -4.2 & -5.4 & -4.8 & -7.7 \\
\hline
\end{tabular}

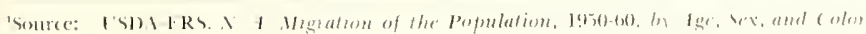

during the specified period. Each county expcrienced net migration of more than minus $17 \mathrm{per}^{\circ}$ cent during the 10-year period. Pendlcton County, with a net migration rate of minus 22 per cent, had a greater loss of population than dicl either of the other counties during this period.

\section{LABOR FORCE OF THE AREA}

The size of a region's labor force is closely related to the size of its population, and chang- es normally oceur in the same direction. Table 6 presents data on changes in population, size of the labor force. and the rate of partieipalion in the labor fores for 1950 and 1960. The Upper Soull Branch Valley incured a proportionately smaller clnange in its labor force than in its lolal population during the 10-year period. llowever, the same situation appears to exist in both the State and the nation. In 1960, 31.6 per cent of the population of the thuce eounlies was in the 


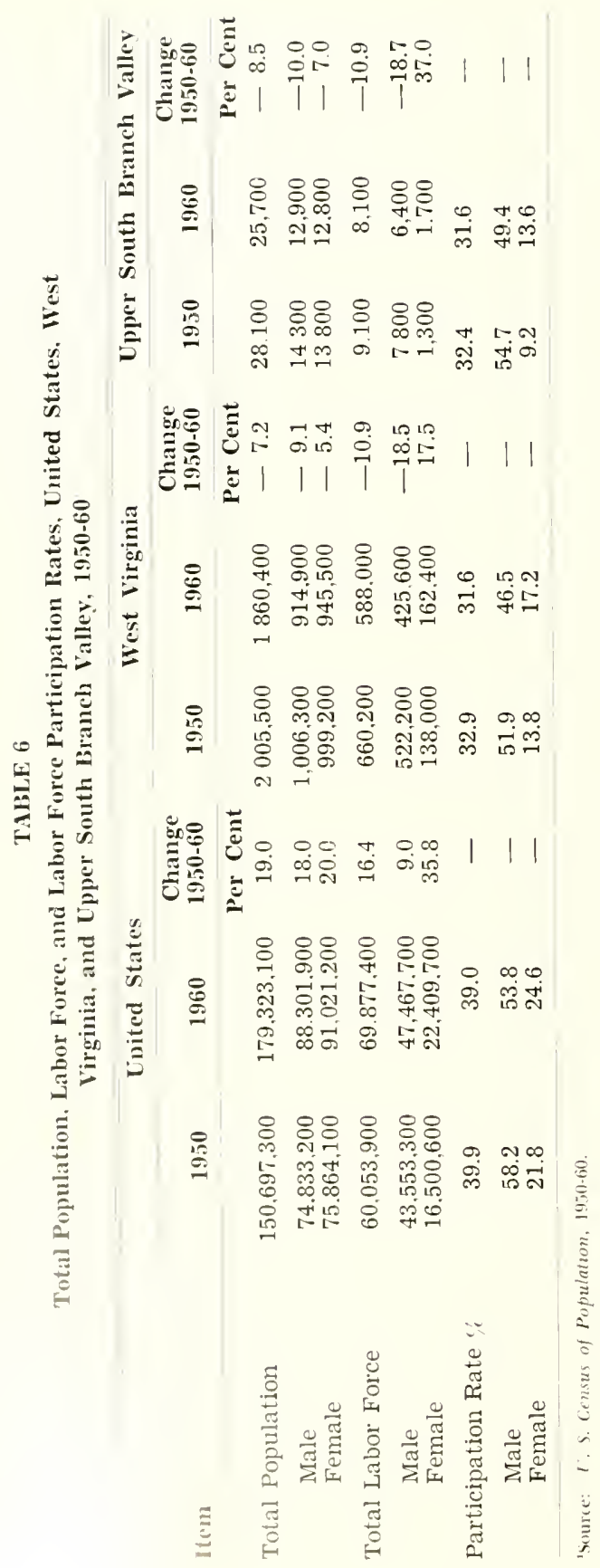


labor force; for the nation, 39.0 per cent. Much of this differential is due to the smaller proportion of females in the labor force in the Upper South Branch Valley. More than 24 per cent of the nation's females was in the civilian labor force in 1960, compared to only 13.6 per cent in the Upper South Branch Valley.

The net decrease in the size of the civilian labor force between 1950 and 1960 in the threecounty area was due to a reduction in the number of males in the labor force.

The average age of members of the labor force was greater for the area than for either the State or the nation in 1960 (Table 7). Eight per cent of the labor force in the study area was over 65 years of age in 1960, but only 4.2 per cent of the State's and 4.6 per cent of the nation's labor force were over 65 .

Over 31 per cent of the total labor force was employed in agriculture in 1960 (Table 8). Despite sizable declines in agricultural employment, the agricultural sector remained the largest single source of employment in the three-county area. The proportion of the labor force employed in manufacturing, trade, and services, was below the national and State average. The area has experienced an increase in employment in non-agricultural sectors during the past three decades, but this increase has not been great enough to offset employment losses in agriculture.

\section{Methodology Used}

Alternative methods exist for analyzing the economic structure of a small area. A decision on the appropriate methodology to use must be made in view of specific objectives and weighted against the time and costs involved in making the analysis.

The objectives of this study were to determine the degree of interdependence existing between industrial sectors in the region and to determine the impact of a change in production in each sector on the income and employment of the area. The various sectors of an area economy do not respond uniformly to changes in demand for locally produced goods and services. Income and employment in one sector may contract with expansion in other sectors, or the rates of expansion may differ. Thus, a measure of the interrelationships between sectors of a region, as well as a measure of the over-all response to a given stimulus (change in demand), is needecl.

A regional adaptation of a Leontief type input-output model was used in this study. The model provided the framework for isolating the linkages between industrial sectors and also for computing income and employment multipliers for each sector.

\section{THE TRANSACTION TABLE}

Input-output analysis is a system of accounts which quantifies the monetary value of goods and services exchanged between sectors of an economy. Sales of output by one sector of the economy are purchases of inputs by other sectors. A transactions table, in which sales and purchases between sectors are recorded, is used to determine the degree of interdependency in the local economy.

TABLE 7

Composition of the Civilian Labor force by $\mathrm{Age}$. United States. West Virginia. and the Upper Sonth Branch Valley. 1960

\section{Age Group}

Over 17 years

Over 25 years

Over 35 years

Over 45 years

Over 65 years

ALL AGES

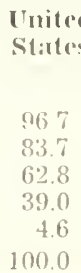

West V'irginia lerer Cent

97.0

84.5

63.8

39.5

4.2

100.0
Epper Soutly Branch Valley

$$
\begin{array}{r}
96.7 \\
843 \\
64.7 \\
42.4 \\
8.0
\end{array}
$$

100.0

'Source: t'. S. Comas of t'ofulatom, 1960. 
TABLE \&

Total Employment and Rate of Employment by Industrial Sector, United States, West Virginia, and the Upper South Branch Valley, 1950-60'

Industrial Sector

Agriculture

Mining

Construction

Manufacturing

Transportation, Communica-

tions. Utilities

Trade

Finance, Insurance,

Real Estate

Services

Public Administration

All Other

TOTAL EMPLOYMENT

Agricultue

Mining

Construction

Manufacturing

Transportation, Communica-

tions, Utilities

Trade

Finance, Insurance, Real Estate

Scl'vices

Public Administration

All Other

TOTAL EMPLOYMENT

\section{United States \\ West Virginia}

$\begin{array}{cc}1950 & 1960 \\ (000) & (000)\end{array}$

$\begin{array}{rrr}6,893.6 & 4252.8 & 61439 \\ 928.3 & 653.9 & 134329 \\ 3398.0 & 3,817.7 & 32,177 \\ 14,453.1 & 17,529.8 & 119,162\end{array}$

$4,346.5$

10388.7

$1,882.7$

$10,119.0$

2.490 .7

903.0

55.803 .5

$1950 \quad 1960$

23,487

59,098

29,285

125,717

$4,458.5$

$11,797.9$

$2,695.5$

13.542 .4

$3,194.3$

$2,703.7$

64646.6
$53,921 \quad 47.331$

$96,952 \quad 97,128$

$9,984 \quad 12,450$

93,422

16580

10,306

628,272
107,008

19.006

17.704

538,214
Upper South

Branch Valley

$1950 \quad 1960$

4.353

169

506

1,013

2,315

89

666

1,267

Employment Rate

\section{Per Cent}

12.4
1.7
6.1
25.8

\section{6}

1.0

9.8

5.1

5.9

27.1

19.0

4.4
11.0
5.4
23.4

49.9

298

844

347

1,086

$\begin{array}{rr}42 & 98 \\ 1.012 & 1.100 \\ 197 & 271 \\ 285 & 168 \\ 8.719 & 7.407\end{array}$

\section{8}

18.6

3.4

18.1

4.5

1.6

100.0
$6.9 \quad 8.6$

$18.2 \quad 15.4$

$\begin{array}{rr}4.2 & 1.6 \\ 21.0 & 14.8 \\ 4.9 & 2.6 \\ 4.2 & 1.7 \\ 100.0 & 100.0\end{array}$

8.8
18.1

2.3
19.8
3.5
3.3
100.0

1.

5.8

11.6

3.4

9.7

4.7

14.7

$\begin{array}{rr}0.5 & 1.3 \\ 11.6 & 14.8 \\ 2.3 & 3.6 \\ 3.3 & 2.3 \\ 100.0 & 100.0\end{array}$

$10,000$.

In Figure 1 a graphic representation of an input-output transactions table is presented. A lotal of " $n$ " industries or sector's are listed in the upper lett hand cornes of the table (Quadrant I) This quadrant is referred to as the process$17 \mathrm{~g}$ of of retion ol the table. All entries in table represent interin(purchases and sales) in the region and considof the model. The interalimn rejresents a the corindustry
1 to industry 2 represents a purchase by industry 2 from industry 1. Therefore, each column entry in Quadrant I for industry 1 represents that industry's purchase during the specified period from other endogenous sectors of the economy. In turn, all row entries in Quadrant I for industry 1 represent that industry's sales to other endogenous sectors.

Quadrant II (Figure 1) is composed of the final demand sectors. Entries in this quadrant represent sales by industries $1,2,3, \ldots, n$ to exogenous final demand sectors $1,2,3, \ldots, \mathrm{m}$. Final demand sectors are unexplained by the 
model and represent sales to final users of the goods and services produced within the region. The number of final demand sectors can and does vary between different regional economies. Exports, i.e., sales by local industries to the rest of the world, deliveries to local household consumption, and capital formation are usually assigned to final demand. The row total, which is the sum of all endogenous transactions, plus sales to final demand, is the total gross output for each industry in the processing quadrant.

In Quadrant III (Figure 1), all purchases by industries $1,2,3, \ldots, \mathrm{n}$ from sources not included in the processing sector are recorded. Sectors in this quadrant are referred to as the final payment sector or section of the table and are represented by one or more rows. Again, the number of final payments sectors can vary depending upon the objectives of the study; but typical entries include depreciation expenditures, payments to local households, government payments (normally in the form of taxes), and all imports or purchases from the rest of the world.
The remaining quadrant of the table, Quadrant IV, represents direct inputs of goods and services to final demand which are not produced by industries in the process quadrant, or Quadrant I. An example of this type of transaction would be government transfer payments to local households.

The accounting procedure employed in the analysis is stated as follows:

$$
\begin{aligned}
& \text { (1) } x_{1}=x_{1}+x^{\prime} \\
& \text { (2) } X,=a+X \\
& \text { (3) } a_{11}=\mathrm{X} \\
& \mathrm{X} \\
& \text { (4) } \begin{aligned}
\mathrm{X} & =\mathrm{n} \\
\mathrm{J} & =1
\end{aligned}
\end{aligned}
$$

Where $\mathrm{X}_{1}$ - total output for sector $\mathrm{i}$

$X_{1}=$ total output for sector $j$

$X_{1}=$ transactions between $i$ and $j$

$\mathrm{X}=$ exogenous sectors

$\mathrm{i} . \mathrm{j}=1,2,3, \ldots, \mathrm{n}$

$\mathrm{f}=1,2,3, \ldots \mathrm{m}$

\section{INDUSTRY}

PURCHASING

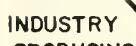

PRODUCING

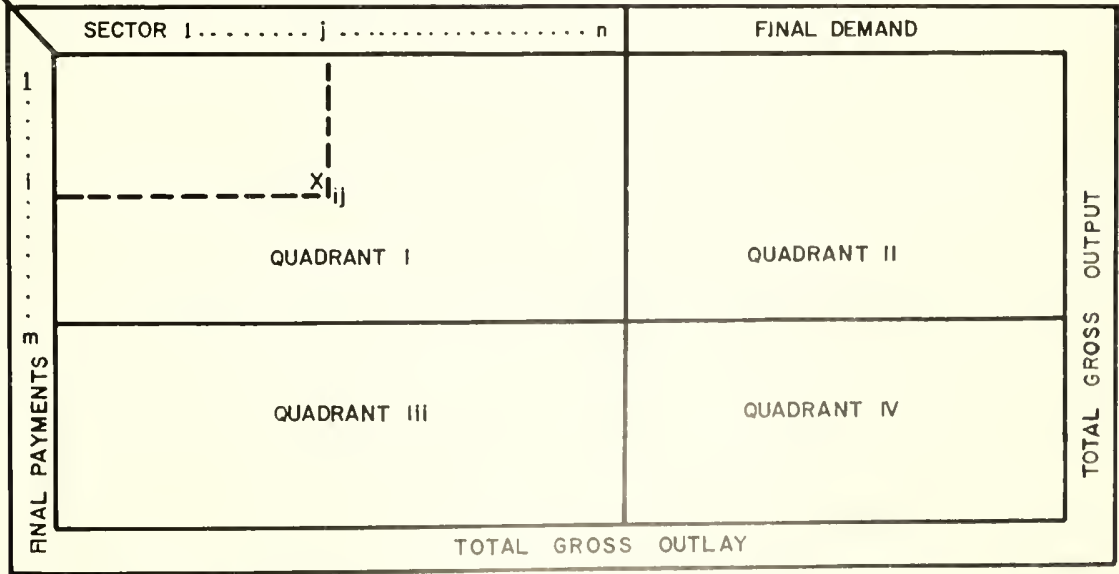

FIGURE 1. Graphic Description of an Input-(Output Transactions Table 
As this procedure states, the economy is comprised of $n+m$ sectors, of which $1,2,3, \ldots, n$ are endogenous or explained by the model. The remaining sectors $(\mathrm{X}$ ) are exogenous or not explained by the model. Equation (1) states that total output $\left(\mathrm{X}_{1}\right)$ is the sum of all endogenous sales by sector i plus sales to the exogenous sectors. The objective of the analysis was to determine the existing relationship between output of a sector $(\mathrm{X})$ and its transaction with other endogenous sectors. Thus, equation (2) states that the demand for the output of sector i by sector $j$ is a function of the output in sector $j$. The functional relationship (a s), subsequently referred to as a technical coefficient, expresses the relationship between output in sector $\mathrm{j}$ and its purchases from sector i (equation 3). Thus, by substitution, total output of sector $\mathrm{i}\left(\mathrm{X}_{1}\right)$ is shown in equation (4) to be the sum of all input requirements from all sectors $j$ plus the value of output moving to the exogenous sector ( $\left.\mathrm{X}_{1}\right)$.

\section{TECHNICAI, COEFFICIENTS}

Each coefficicnt is an estimate of the purchase per unit of output by a given sector in the processing quadrant from another sector in this quadrant. By adding the coeflicients for any columm, total interindustry requirements by a given sector to produce a unit of output can be determined.

The coeficients represent only the direct requirements per unit of output by sectors and do not include any indirect or generated requirements. An increase in final demand for the output of onc endogenous sector requires that the given sector increase its purchases of the output of other sectors. To increase their output, these other sfetors mist, in turn, purchase more of the output of still other sectors. The sum of all generated output resulting from the increase in finat demand for the ontput of the given sector is referred to as the multiplier effect. Computation of th totul generative or multiplier effect 4' in, tougr in final demand for each sector economy was accomplished matical process known as

\section{ASSUMPTIONS OF INPU'T-OUTPUT}

\section{ANALYSIS}

In its general form, an input-output model establishes a specific set of input-output relationships between sector's. It is therefore assumed that:

(1) Structural relationships between economic sectors can be identified by a unique set of input-output coefficients."

(2) Each commodity is supplied by a single industry or sector of production.

(3) The inputs purchased by each sector are a lunction of the level of output of that sector only.

(4) The total effect of carrying on several types of production is the sum of separate effects, i. e., there are no external economies of scale.

(5) A unique set of regional trading patterns exists, i.e., the geographical distribution of sectoral sales and purchases is fixed in the transactions table.

\section{ADVANTAGES OF INPUT-OUTPUT ANALYSIS}

A major advantage of input-output analysis is that there is no requirement as to the number of sectors included in any quadrant in the transaction table. The only requirement is that there must be one row for each column in the processing quadrant (Quadrant I, Figure 1). The number of sectors included in any quadrant can be determined by the industrial composition of the region, availability of data, or detail of results desired. For example, deliveries to final demand can be divided into such entries as households, government, and exports, with exports further separated on the basis of destination of the products. On the other hand, all deliveries to final demand can be aggregated into a single entry.

Several objectives can be accomplished with input-output analysis by shifting sectors from one quadrant to another. For example, it is possible to shift a sector such as households from the final demand quadrant to the pro- 
cessing quadrant if the objective is to explain the level of household income. Conversely, if the objective is to analyze the interindustry effects of changes in residential construction activity, the residential construction industry can be changed from a processing to a final demand sector.

\section{LIMITATIONS}

Data developed for a regional transactions table cover interindustry sales and purchases within the local economy during a given period of time. The ability of fixed coefficients derived from these data to accurately depict the response of the local economy to a change in final demand must be considered in evaluating the results of a regional input-output analysis. A change in technology, regional trading patterns, or the product mix associated with an expansion or contraction of final demand affects the accuracy of the results of the study.

Data requirements for a transactions table are considerable. Therefore, the quality and quantity of available data also affect the reliability of relationships established in the transactions table.

\section{VAIUATION OF OUTPUTS AND INPUTS}

Input-output analysis is a study of the flows of goods and services within a region. These flows are usually stated in monetary terms. Value of output is measured in terms of producer's prices rather than purchaser's prices. The difference between the two values represents items such as transportation costs, wholesale and retail trade margins, and excise taxes."

In most transactions tables, commodities or groups of commodities are charged clirectly to the sector using the commodity. This requires that the transportation and trade, and insurance sectors of the economy be margined-that is, only the value added to goods through provision of time and place utility is attributed to these sectors. Therefore, total gross output lor these sectors is defined as total sales less the cost of goods sold. A direct allocation to the consuming sector is made for goods for resale from these sectors. This procedure indentifies the direct linkages between the producing and purchasing sector's.

\section{CAPITAL TRANSACTIONS}

Sales and purchases bet we e $n$ productive sectors of an economy can take two forms: (1) transactions on current account, i.e., purchases of goods and services which are consumed during the current period; and (2) transactions on capital account. All sales by firms in the processing sectors of the matrix on capital account are recorded in a capital formation column in Quadrant II of the transactions table (Figure 1). All expenditures by firms in the processing sectors on capital account are summarized in a capital row in Quadrant III. In effect, the capita] row records allocation of funds by sector to depreciation expenditures during the base period. All other rows and columns in the table show flows of goods and services on current account.

\section{The Upper South Branch Transactions Table}

Firms in the study area were grouped into the 14 processing sectors presented in Table 9. The composition of each sector is given below.

(1) The agriculture sector inchudes all operations engaged in agricultural production such as livestock, crop, and fruit or vegctable farms, and also includes hatcheries, artificial inseminators and veterinarians, and others who provide service to farming operations on a contract or fee basis.

(2) The mining scetor includes those establishments engaged in coal mining, limestone quarrying. and the extraction of cructe petroleum and natural gas.

(3) The contract construction sector includes those firms ongaged in the construction of buildings. special trade contractors engaged in specinlized construclion activities such as plumbing. painfing, plectrical work and carpentry and pencral contractors.

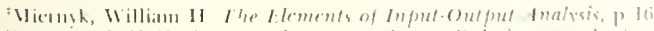


(4) The food nanufacturing sector includes all establishments engaged in either the slaughter, clressing, preparation or packing of meats or meat products (including poultry); the manufacture or processing of dairy products; the manufacture of grain products such as flour lor human consumption or prepared feeds for livestock or poultry; the manufacture of bakery products; or the manufacture of bottled and canned soft drinks.

(5) The apparel manufacturing sector includes those establishments engaged in producing clothing and fabricating products by cutting and sewing purchased textile fabrics.

(6) The wood and wood products sector includes firms engaged in the cutting of timber or pulpwood; sawmills, planing mills, plywood mills and others engaged in producing wood basic materials; establishments engaged in manufacturing finished articles, including furniture, made of wood or wood substitutes.

(7) All firms engaged in printing and publishing, the production of leather and leather products, and the production of stone, clay, glass or concrete products were grouped together into a single sector called other manufacturing.

(8) The transportation sector includes all local trucking activity, plus the stockyard operations in the area.

(9) The communications and utilities sector includes electrical companies, telephone companies, a radio station, and a firm which generates electricity.

(10) All wholesale and retail trade in the three-county area was aggregated into a single wholesalc and retail trade sector.

(11) Commercial banking establishments were included in the commercial banking sector.

(12) The other finance, insurance and real estate sector includes credit agencies (other than $b^{2} k+1$, insurance agencies, and real estate

rvien sector includes establishand other lodging places; jersonal, business, mrdical, legal, inal and misinstitutions
(14) The local government sector includes all economic activity originating from county and municipal governments; public school operations were also included in this sector.

The transactions table developed for the threecounty area inclucked three exogenous sectors:

(1) The households sector. Included in the household column of the table are all sales of goods and services by local business establishments to local households. In turn, all payments to local households by local businesses in the form of wages, salaries, proprietary income, dividends, rents and business transfers are included in the households row of the table.

(2) All transactions on capital account. All sales by local processing firms to final users of local goods and services for new capital formation are given in the gross private formation column of the table. In turn, all expenditures on capital account (depreciation allowances) are included in the other exogenous row of the table.

(3) All transactions with the rest of the world. All sales by local industry to the rest of the world are included in the exports column of

\section{TABLE 9}

Sectors and Corresponding standard Industrial Classification Codes (S.I.C.) Ineluded in the Upper South Branch Transaction Table

\section{Sector Name}

Agriculture

Mining

Contract Construction

Food Manufacturing

Apparel Manufacturing

Wood and Wood Products

Other Manufacturing

Transportation

Communications and Utilities

Wholesale and Retail Trade

Commercial Banking

Other Finance, Insurance,

Real Estate

Services

Local Government
S.I.C. Codes

$0110-0729$

$1010-1499$

$1510-1799$

2010 - 2099

2310 - 2319

2410 - 2599

$2710-2799$

$3110-3199$

$3210-3299$

$4010-4789$

4810 - 4971

$5010-5999$

$6020-6028$

$6110-6799$

7010 - 8999

Except 8211

$9301-9390$

8211

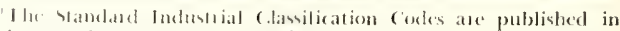
the samdard Industial CIassification Manual, Office of Statis. fital stoudathe Bureau of the Budget, 1967. 
the table. All purchases by local establishments from the rest of the world (imports) are included in the other exogenous row. As only local county and municipal government activity is included in the endogenous sector of the transaction table, all transactions by local residents and business establishments with state and Federal governmental units are included as exports and imports.

\section{Data Collection}

Data pertaining to the size and distribution of local interindustry sales and purchases are not directly available in published sources. Therefore, primary data were secured to supplement information from secondary sources. A field survey of a sample of local business establishments was used in all sectors of the economy with the exception of agriculture, communications, utilities, and local governmental units. A group survey was used to supplement secondary data in the agricultural sector. Secondary sources of information were used to obtain the data required for all other sectors not covered by the field and group survey. In addition, secondary sources of data were employed to obtain estimates for the households sector.

Table 10 presents the total number of establishments, sampling rate, and number of establishments interviewed in the field survey. The sampling rate varied from 10 per cent in the trade and services sectors to 100 per cent in th commercial banking sector. With the exceptio of the manufacturing, mining, and commerci banking sectors establishments were random. selected. Sufficient data were available in tl mining and manufacturing sectors to identif establishments which dominated a sector terms of employment and output. These estal lishments were selectively included in the sam ple to insure their coverage. Additional firn were randomly selected to meet the samplin rate specifications. Two or more firms wer selected from each two-digit classification. Sixt of the 93 firms selected provided the inform tion requested (Table 10 ).

A group survey was used to supplement sec ondary data on the agricultural sector. A meet ing was held with farm operators and the loce county agent in each of the three counties in th study area. An effort was made to select group of farm operators who were geographically di tributed throughout cach county, and a tota of 22 farm operators participated in the thre groups. Each farm operator filled ont a question naire concerning the geographical and sectora distribution of revenues and expenditures for hi farming operations during 1965. In addition each group discussed the geographical distri bution of sales of a series of farm commoditic for all farms in the county. In this manmer, cac group allocated all sales of farm products b type of product for the county in 1965 .

TABLE 10

Total Number of Establishments, Sampling Rate, and Completed Interviews by Two-I Digit S.I.C.

\begin{tabular}{|c|c|c|c|c|c|c|}
\hline Sector & S.I.C. & $\begin{array}{c}\text { Estimated } \\
\text { Number of } \\
\text { Establishments }\end{array}$ & $\begin{array}{l}\text { Simpling } \\
\text { No. }\end{array}$ & $\underset{\because}{4}$ Rate & $\begin{array}{l}\text { Number } \\
\text { Intervieweel }\end{array}$ & $\begin{array}{l}\text { Per Cent } \\
\text { Interviewed }\end{array}$ \\
\hline Agricultural Services & 07 & 9 & 4 & 45.0 & 3 & 33.3 \\
\hline Mining & $12-14$ & 13 & 9 & 70.0 & 4 & 30.7 \\
\hline Contract Construction & $15-17$ & 22 & 6 & 25.0 & 0 & 0.0 \\
\hline Manufacturing & $19-39$ & 50 & 23 & 45.0 & 15 & 30.0 \\
\hline Transportation & $42-47$ & 15 & 4 & 25.0 & 2 & 13.3 \\
\hline Trade & $50-59$ & 220 & 24 & 10.0 & 19 & 8.6 \\
\hline Commercial Banks & 60 & 5 & 5 & 100.0 & 4 & 80.0 \\
\hline $\begin{array}{l}\text { Other Finance, Insurance, } \\
\text { Real Estate }\end{array}$ & $61-65$ & 23 & 5 & 20.0 & 2 & 87 \\
\hline Services & $70-89$ & 116 & 13 & 10.0 & 11 & 9.5 \\
\hline TOTAL & $\ldots$ & 473 & 93 & 200 & 60 & 12.7 \\
\hline
\end{tabular}

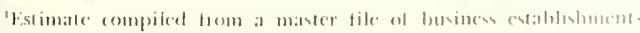




\section{Matrix Construction}

Actual construction of the transactions matrix involved the reconciliation of data independently derived for each processing sector. For each sector the sales to and purchases from each sector were determined. Each endogenous sale is by definition also an enciogenous purchase. Thus, a convenient check was available on all cndogenous transactions.

Without exception, estimated sales by industry $\mathrm{i}$ to inclustry $\mathrm{j}$ differed from estimated purchases by industry j from industry $i$. When the reason for the difference could not be determined, data from the source judged to be the more reliable were used. More data were available from some sectors than from others and the quality ol the data was juclged to be better for some sectors than for others. For example, retailers were usually able to quantify and trace the distribution of business purchases from their records. On the other hand, they were forced to estimatc the distribution of sales during the same period.

No cross-checks were available for exogenous sectors. For example, estimates of sales by the trade sector to local households could not be compared with data on the sectoral distribution of local household expenditures. Also, it was impossible to independently check the magnitude of imports and exports by sector.

\section{Analysis of the Local Economy}

The transactions table for the Upper South Branch economy for 1965 is presented in Table 11. The northwest portion of the table is the processing quadrant. Sectors in this quadrant are endogenous. All other sectors of the table are exogenous. Columns labeled "households," "gross private capital formation," and "exports" comprise the final demand sectors. Rows labeled "households" and "other exogenous" comprise the final payments sectors.

Each column entry in the table represents a purchase by the sector named at the top of the column from the sector named at the left. In turn, each row entry represents a sale by the

Upper South Branch Transactio INDUSTRI

\begin{tabular}{|c|c|c|c|c|c|c|c|c|}
\hline 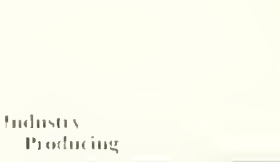 & 咅 & 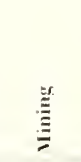 & & $\begin{array}{l}\overline{\bar{E}} \\
\overline{\bar{E}} \\
\overline{\bar{E}}\end{array}$ & 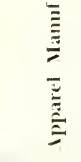 & 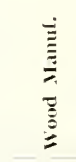 & 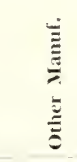 & 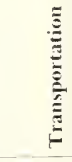 \\
\hline lestenitmere & 715.1 & 1) & 0 & 915.1 & 0 & 80.5 & 0 & 1.5 \\
\hline viung & 8.5 .2 & 0 & 11.0 & 3.8 & 1 & 0 & 24.6 & \\
\hline 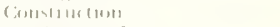 & 7.5 .7 & 1.0 & (i) 11 & 0 & 1) & 1) & 2.5 & 0 \\
\hline lerel Vianuf. & $2,8 \div \div .1$ & () & 0 & 9.8 & 11 & 5.0 & 0 & 3.9 \\
\hline 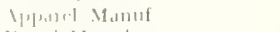 & (1) & 11 & 0 & 11 & "1 & 0 & 1) & 0 \\
\hline 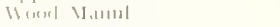 & $4 ; 0$ & 1.; & 15,0 & 0 & () & 0 & 0 & \\
\hline IMh, V:anuf. & 8.2 & (1) & 13.5 & 91 & () & 0.1 & 0.3 & 1.6 \\
\hline 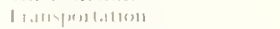 & 133 & 319.0 & 16.3 & 1 & 0 & 7.5 & 3.4 & 0 \\
\hline iommi Italistes & 197.1 & 61.7 & 18.6 & 15.8 & ! & 31.1 & 21.1 & 14.9 \\
\hline 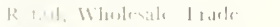 & $\times 16.1$ & 391.1 & 10.51 & 19.1 & fi & 13.9 & 10.3 & 66.7 \\
\hline (6) y binking & 125.11 & .9 & 33.1 & 3.9 & 1) & $7+$ & 1.1 & 24.1 \\
\hline 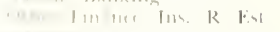 & 31.1 & 1.7 & 16.7 & 11.6 & 0.1 & 2.1 & .5 & 3.5 \\
\hline & 171.6 & 2.7 & 23.3 & 5.1 & 11.7 & 18.9 & 10.3 & 22.8 \\
\hline $16 \times 12$. & $1+2.2$ & 7.5 & 2.3 & 25.5 & 11.6 & 2.1 & 1..0 & 33 \\
\hline 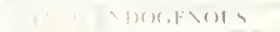 & $5,121.11$ & 1711 & 399.7 & 1.068 .8 & 11.5 & 1722 & 83.1 & $1+2.3$ \\
\hline $14 \times 16+1+x$ & 307,7 & $3.5,9911$ & $2,113,9$ & 721.9 & 3279 & $1,530.9$ & 131.7 & 872.9 \\
\hline 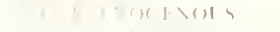 & 10.7218 & 3.9760 & $3,8610.4$ & 6.517 .1 & 1.919 .8 & $2.25 \times .7$ & 1.123 .8 & 5.52 .6 \\
\hline Why ot $111 \mathrm{IY}$ & 19.218.; & 7.97 .5 & 11.612 .0 & 8.3081 & 2.289 .2 & $3961 \times$ & 1,63866 & 1.567 .8 \\
\hline
\end{tabular}


industry named at the left to the sector named at the top. Therefore, an examination of the sales distribution of a given processing sector involves a movement across that industry's row in the transactions table. An examination of the expenditure pattern of a specific processing sector involves a movement down that industry's column.

Data in the exogenous sectors of the table provide considerable information on the economic structure of the area's economy. Figure 2 shows the percentage of total gross output by processing sector, which represents a delivery of locally produced goods and services to final demand. Deliveries to final demand as a per cent of total gross output varied from 100 per cent in apparel manufacturing to 58.5 per cent in mining. More than 84 per cent of total gross output originating in all processing sectors was delivered to final demand.

A small area economy is usually a relatively open economy, i. e., a relatively large proportion of all economic transactions is made with the rest of the world. Figure 3 shows the proportion of gross output exported by each processing

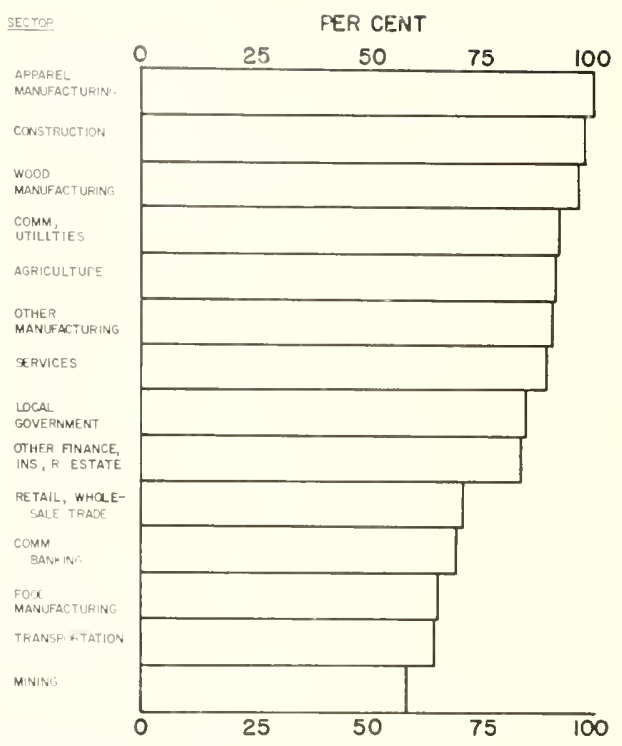

FIGURE». Deliveries to Final Demand as a Per Cent of Total Gross Output by Industrial sector

Table, 1965 ('Thousands of Dollars)

\section{C11.1S1NG}

\begin{tabular}{|c|c|c|c|c|c|c|c|c|c|c|}
\hline 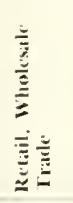 & 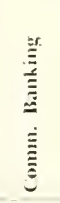 & 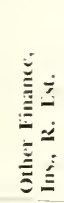 & 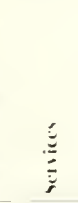 & $\begin{array}{l}\vdots \\
\vdots \\
\vdots \\
\vdots \\
\vdots\end{array}$ & 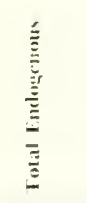 & 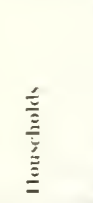 & 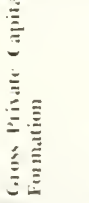 & $\frac{\vdots}{\underline{E}}$ & 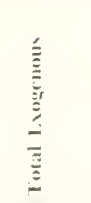 & 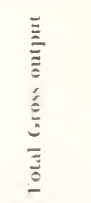 \\
\hline 0 & 1) & () & () & 0) & 1.772 .2 & $1,1175,9$ & (1) & 111.110 .1 & $17.116 . .8$ & 19218 \\
\hline 32.0 & 0 & 1.0 & 20 & 81 & $3,305.1$ & 117.7 & (1) & $y^{\prime \prime}+1$ & $1,0^{-2}-1$ & 71,77 \\
\hline 79.5 & 1.8 & 0 & () & $x .8$ & 210.3 & 171 & $10,70,3,0$ & 1936 & $11.71 \%$ & $11,1,1 \geq 0$ \\
\hline 1.8 & 0 & () & () & 6.2 & $2 . x \times 1 . x$ & Ilisto & (1) & ;, 210.3 .3 & $3,1 \cdots 3$ & \& $\| x+1$ \\
\hline () & () & J & 1) & 0 & is & (1) & 0 & $2.2 \times 12$ & $20 \times 4=$ & $2 \cdot 2+2+$ \\
\hline () & 0 & 0 & () & 0 & $111 \ldots$ & (1) & 11.2 & $3.414,1$ & $\because 82$, & $\forall 41,1.5$ \\
\hline 73.5 & 3.3 & 2.0 & $1, x$ & 17.11 & I $(i t) .1$ & $1 \geq 7+1$ & 1134 & $12: 4 ; 0$ & $11,8$. & 10,180 \\
\hline 123.0 & 0.2 & () & 8.3 & (i.) & $\because 11$ & $177 \mathrm{I}$ & (1) & iाile & 116 & $111^{-} 4$ \\
\hline $21 \% 7$ & 12.8 & $13.1 \mathrm{j}$ & $8 \times .5$ & 39.8 & $x^{2} \geq 1.1$ & 法0 & 11 & $8.65+11$ & $111=1$ & 1,11 \\
\hline 9012 & 2.3 & 1.3 & 636 & 30.6 & $2.1 \times 2.1 \mathrm{i}$ & 3.157 .8 & $3(1,2,1\rangle$ & 1,$1 ;=11$ & ; 41 & 1,9 \\
\hline 70.1 & 0 & 2.7 & ห.9 & 5.1 & $28 ; 1$ & 3,25 & (1) & $1,2-4$ & $1=$ & 11111 \\
\hline 25.9 & 21 & 0 & 19 & 21 & 811.6 & $371, \overline{1}$ & $1 \div$ & & & +1 \\
\hline 11.1 & 153 & (i.) & 11.2 & $\tau(1) .0$ & $38 \times 3$ & $12,7,2,7$ & (1) & is * * 1 & & $11-x$ \\
\hline 70.9 & 5.1 & is & 211 & 71 & $37 \div 6$ & i11: & & $1 \mathrm{in}=1$ & $1 \cdot 1=$ & $\ldots, 1$ \\
\hline .761 .0 & 16.5 & $35 . x$ & $209 . x$ & $2(3) 1.6$ & $1,3.1666,8$ & & & & & \\
\hline $3,967.3$ & $111 \%$ & 3223 & 2.1511 & $1,693.9$ & 21.972 .6 & : 11.2 & $44 !$ & (x) 10 & $1-=1 \quad 1$ & 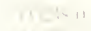 \\
\hline $.95 \times 6$ & 1.8 .1 & 111.5 & 1.3189 & 379.6 & $H(i, x) \leq 1 ;$ & 237276 & $H_{1}, i$ & $|11,1|$ & & $4: 1, x$ \\
\hline 7.686 .9 & 916.1 & .802 .6 & 3.682 .8 & 2.25 .1 & S19187 & 31.21800 & 促资: & $1,1 \quad+1$ & & $1111,1-$ \\
\hline
\end{tabular}


secto1: Exports as a per cent of total gross output raried from 100 per cent in apparel manufacturing to 4 per cent in local contract construction. About 58 per cent of total gross output was exported. Total exports for all endogenous sectors can be obtained by adding the entries in the cxport column (Table 12). Agriculture, manufacturing, communications, and utilities accounted for approximately 79 per cent of total export transactions made by all processing sectors in 1965.

Local household consumption used approximately 12 per cent of total gross output originating in the 14 processing sectors during the period studied. However, there was a great deal of variation between sectors with respect to sales to local households as a per cent of total gross output (Figure 4). Those sectors which exhibited a relatively great dependence upon export (external) markets (Figure 3) in general show local household consumption to be a relatively small component of total final demand.
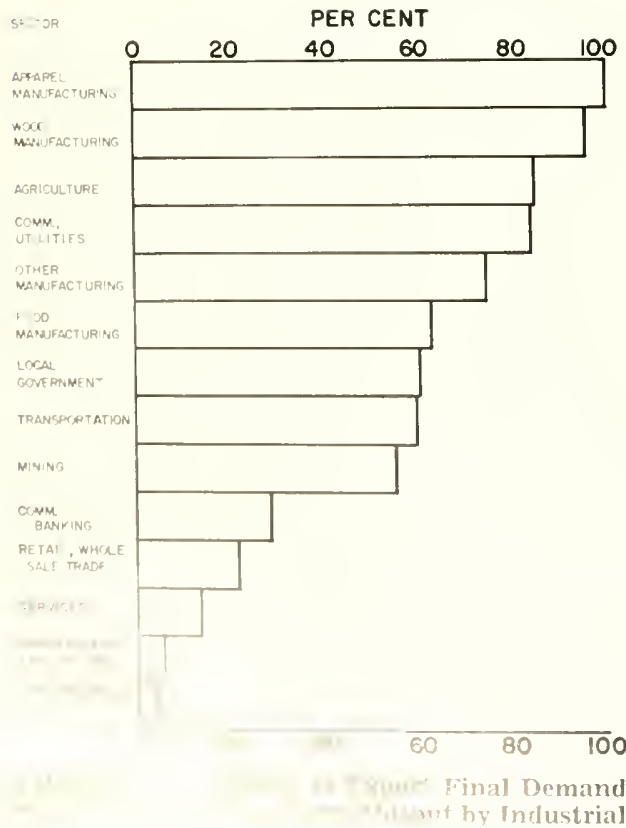

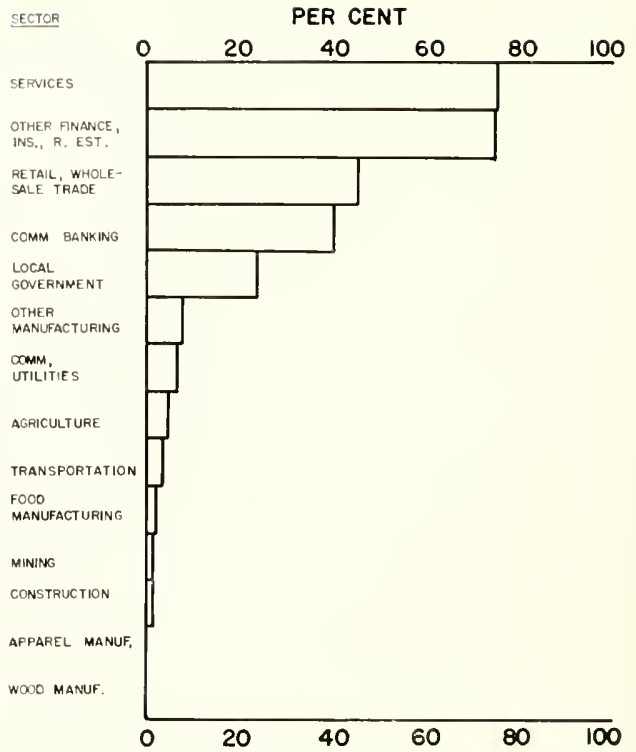

FIGURE 4. Household Consumption as a Per Cent of Total Gross Output

TABLE 12

Estimated Distribution of Total Exports by Local Sector, 1965

Sector

All Local Sectors

Agriculture

All Manufacturing

Food

Wood

Apparel

Other

Communications, Utilities

Mining

Trade

Local Government

Transportation

Services

Construction

Commercial Banking

Other Finance, Insurance,
Total Value of Exports

(000)

$\$ 47.549 .2 \quad 100.00$

$16,410.4 \quad 34.51$

$12,595.8 \quad 26.48$

$5,263.6 \quad 11.07$

$3.806 .1 \quad 8.00$

$2,289.2 \quad 4.81$

$1.236 .9 \quad 2.60$

$8.675 .0 \quad 18.24$

$4524.4 \quad 9.52$

$1,685.6 \quad 3.54$

$1,382.0 \quad 2.91$

$949.6 \quad 2.00$

$522.0 \quad 1.10$

$493.6 \quad 1.04$

$278.3 \quad 0.59$

$\begin{array}{ll}32.8 & 0.07\end{array}$ 


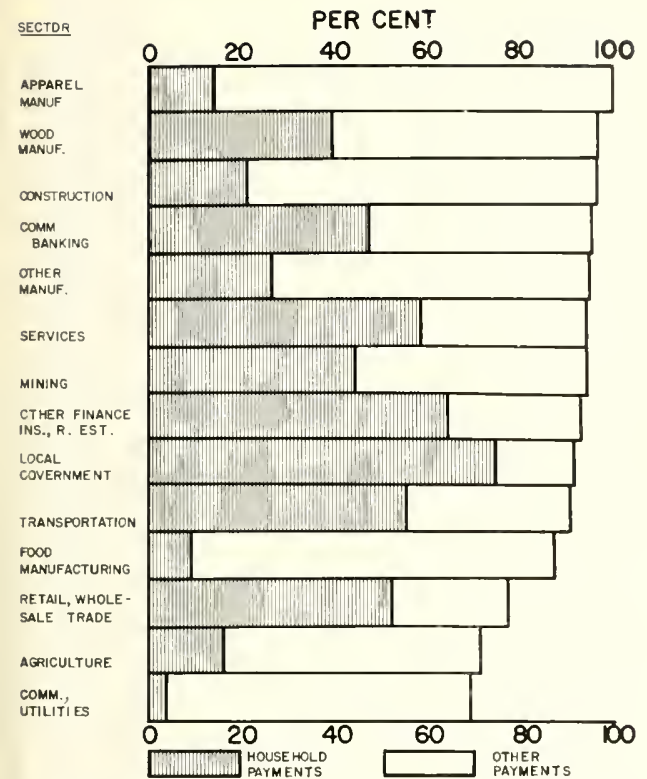

FIGURE 5. Final Payments as a Per Cent of Total Gross Ontput

In Figure 5 a graphic summary of final payments as a per cent of total gross output for all endogenous sectors is presented. Final payments represent expenditures made by each endogenous sector to sectors considered to be exogenous to the model, i. e., local household payments, expenditures on capital account, and imports from the rest of the world. Final payments varied from almost 100 per cent of total gross output in apparel manuacturing to 69 per cent in communications and utilities. Local household payments as a per cent of total gross output ranged from 74 per cent in the local government sector to 4 per cent in the communications and utilities sector.

\section{STRUCTURAL INTERIOEPNIDENCE}

The degree of interdependence between cndogenous sectors of the local economy is measured by the relative magnitude of transactions in the processing quadrant of the transactions table. The per cent of the total gross output of each processing sector that is represented by endo- genous transactions is presented in Figure 6.

For example, purchases by the agricultural sector from all processing sectors are equal to nearly 29 per cent of the value of the gross output of agriculture. Endogenous purchases by the apparel manufacturing sector, which purchases nearly all of its raw materials outside the region, are equal to less than 1 per cent of gross output of the sector. Apparel manufacturing firms export all of their final goods; thus endogenous sales by that sector are zero.

If final demand increases by a given amount for the products of a sector for which endogenous transactions are equal to a high per cent of its gross output, the impact on the local economy will be much greater than for an equal increase in demand for products of a sector for which endogenous transactions make up a small per cent of its gross output. Quantification of the dollar reaction of each sector in the local economy to a dollar change in the level of final demand for locally produced goods and services was achieved by the computation of a direct requirements matrix.

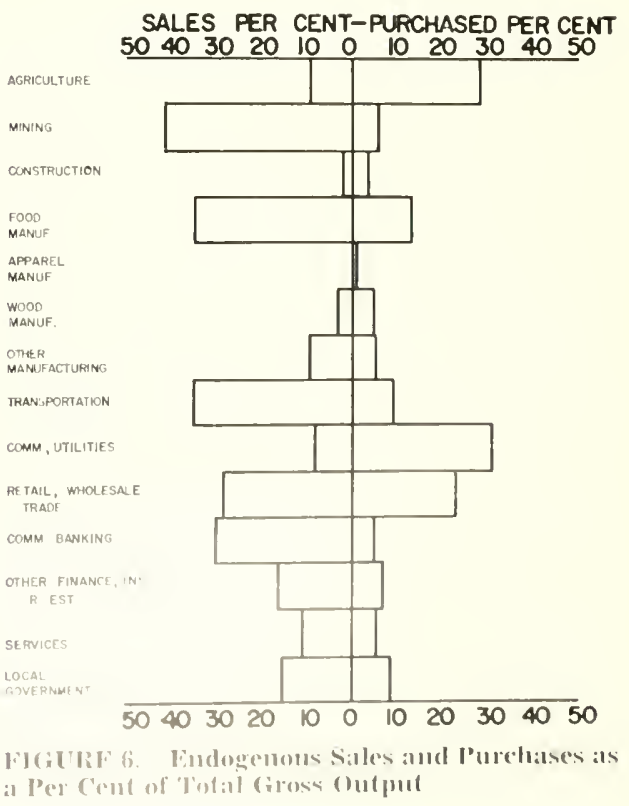


Direct Requirements or Technical Coefficient Matrix

The direct requirements matrix, which was derived by dividing each column entry in the processing sector of the transactions table by that scctor's adjusted total gross output," is presented in Table 13

Each column entry in the table is an estimate of the direct requirements from the industry named at the left, per dollar of output, by the industry named at the top. For example, the food manufacturing sector purchases \$.1137 (11.37 cents) worth of products and services from agriculture for each $\$ 1.00$ of gross output by the food manufacturing sector.

Table 13 also includes household payments and other exogenous payments as per cent of total gross output. These coefficients permit a summation to 1.00 for the coefficients listed in each column.

\section{Interdependency Coefficients}

The direct requirements matrix provides an estimate of the initial effect on the endogenous sectors of the local economy when one sector realizes a dollar change in total gross output. Inversion of this matrix provicles an estimate of the total generative or multiplier effect for all enclogenous sectors, which results from a dollar increasc in final demand for the goods and services protuceri by each cndogenous sector.

The inverted direct requirement matrix for the Upper South Branch economy is presented in Table 14. Each column cntry is the total direct, plus indirect, requirements from the industry named at the left, per dollar of sales to final demand. by the industry named at the top of the table.

In bricif, the inverted drect requirements hatrix estimates the adclition to total output in 11. i *ton resulting from a one dollar change di.mond in the $\mathrm{i}$ sector. Increases in nonls outpunt in excess of direct necrssaly berause initial (direquirements gener- ate additional rounds of transactions within endogenous sectors of the local economy. This can best be illustrated by tracing the sectoral changes resulting from an increase in sales to final demand of one dollar in one endogenous sector. Table 15 shows column coefficients from the matrix of direct requirements (Table 13) and direct and indirect requirements (Table 14) for the agricultural sector. To increase output by the agricultural sector by one dollar, agricultural firms make direct purchases of 28819 dollars worth of goods and services from all endogenous sectors. However, this is not the total increase in output of all endogenous sectors resulting from an increase of one dollar in agricultural sales to final demand. There also will be an indirect increase in output of all endogenous sectors of .05851 dollars. This is the increase required by all endogenous sectors from each other to meet the increased requirement of the agricultural sector. Sectors selling inputs to agriculture must in turn purchase more inputs to meet increased sales to agriculture. For example, when the food manufacturing sector expands its production because of an increase in the demand for the products of agriculture, the increased clemand thus generated will be felt by endogenous sectors which sell to the food manufacturing sector. The direct effect upon food manufacturing per dollar change in final demand for agricultural products is about .15 dollars. However, total output required from the food manufacturing sector to support the delivery of one dollar of agricultural output to final demand is approximately .16 dollars. The same reasoning applies to all other entries in Table 15.

In the prior discussion, households have been considered as an exogenous sector of the transactions table. Thus, output adjustments to a unit change in final demand estimated by the direct and indirect requirements matrix (Table 14) do not include the generative effect of new rounds of local houseliold consumption expenditures.

The household sector can be considered as an endogenous sector to estimate the impact of local consumption expenditures on sectoral 


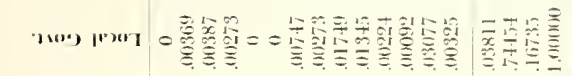

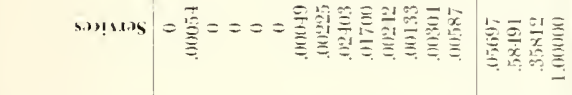

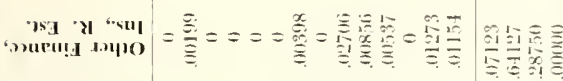

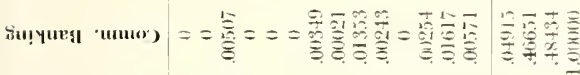

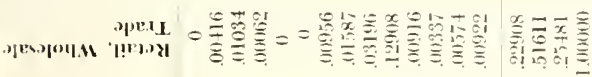

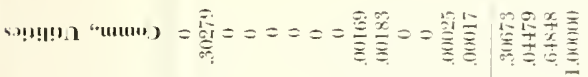

пo!nethoduet

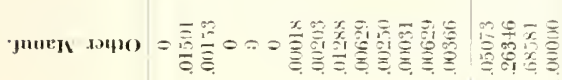

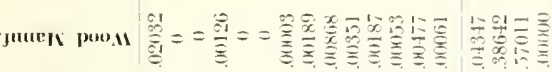

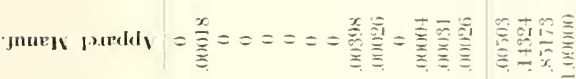

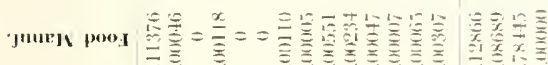

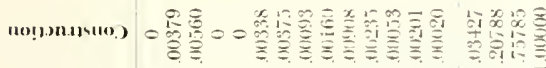

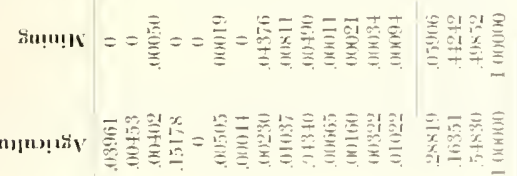

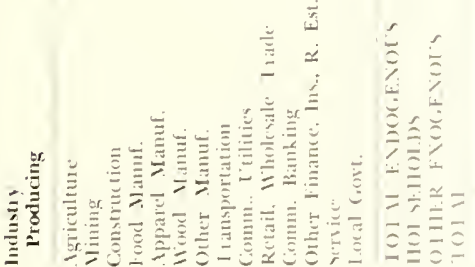

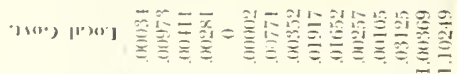

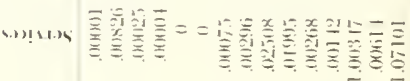

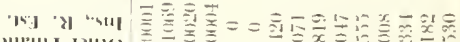

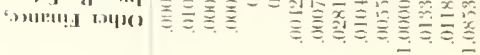

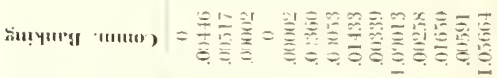

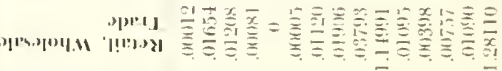

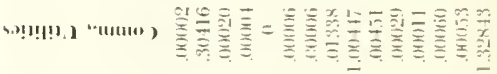

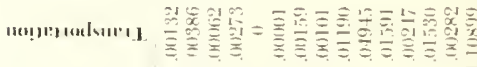

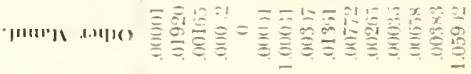

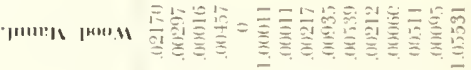

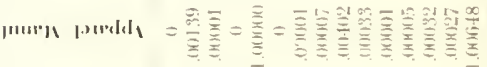

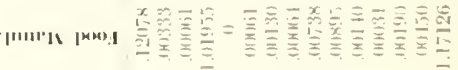
(10!1ㄴ,

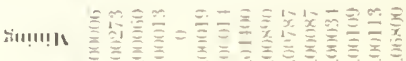
ルแ!иル,

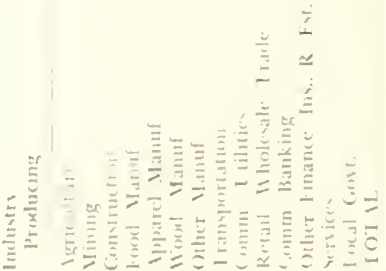


output. In other words, changes in output by endogenous sectors increase payments to local households, i.e.. wages, salaries, rents, profits, etc. In turn, increased household payments generate more demand for additional endogenous goods and services and so on. This procedure was followed, i.e., the household sector was included in the processing quadrant. A matrix of direct requirement coefficients was computed and the inverse of the matrix was obtained. The inverse matrix is presented in Table 16 .

Again, each entry in Table 16 shows purchases from the industry named at the left of the table by the industry listed at the top for each unit of output sold to final demand. However, the coefficients in Table 16 include the output generated by additional consumer spending. The impact of increased consumer spending in response to an exogenous change in final demand is referred to as an induced effect.

Using the agriculture sector as an example, data in Table 16 indicate total endogenous output, excluding the local household sector, must total .45072 dollars $(.74902-.29830$ dollars $)$ in addition to the initial dollar change in demand to sustain the delivery of an additional dollar's worth of agricultural sales to final demand. Comparison with the corresponding column total in Table 14 shows that the induced effect of additional household expenditures on the gross output of the 14 original processing sectors was .10402 dollars (1.45072 dollars - 1.34670 dollars). Similar comparisons can be made with all other entries in the table to isolate the induced effect of increased household expenditures on gross output.

The totals for each of the columns in Table 16 indicate the estimated total impact on the area economy that can be expected from a dollar change in the final demand for the products of each individual sector. For example, a dollar change in the final demand for agricultural products will generate a total of $\$ 1.74$; a dollar change in the final demand for the products of apparel manufacturing is estimated to generate a total of $\$ 1.24$; and a dollar change in the

TABLE 15

Illustration of the Sectoral Response to a Change in Final Demand in the Agricultural Sector of the Local Economy'

Direct Re-
quirements

Sector

\section{Agriculture}

Mining

Construction

Foor Manulacturing

Apparel Manufacturing

Wood Manufacturing

Other Manufacturing

Transportation

Cromrnunirations. Utilities

Rer il. Wholesale Trade

$f$.ank rial Banking

Insurance.
(A)

.03961

.00453

.00402

.15178

0

.00505

.00044

.00230

.01037

.04340

.00665

.00160

.00822

.01022

.28819
Direet and In-
direet Require-
ments

(I)

Dollars

.06046

.00956

.00495

.16123

0

.00538

.00131

.00380

.01443

.05405

.00777

.00195

.00979

.01202

.34670

\section{Indirect \\ Require- ments ${ }^{4}$}

(C)

.02085

.00503

.00093

.00945

0

.00033

.00087

.00150

.00406

.01065

.00112

.00035

.00157

.00180

.05851 


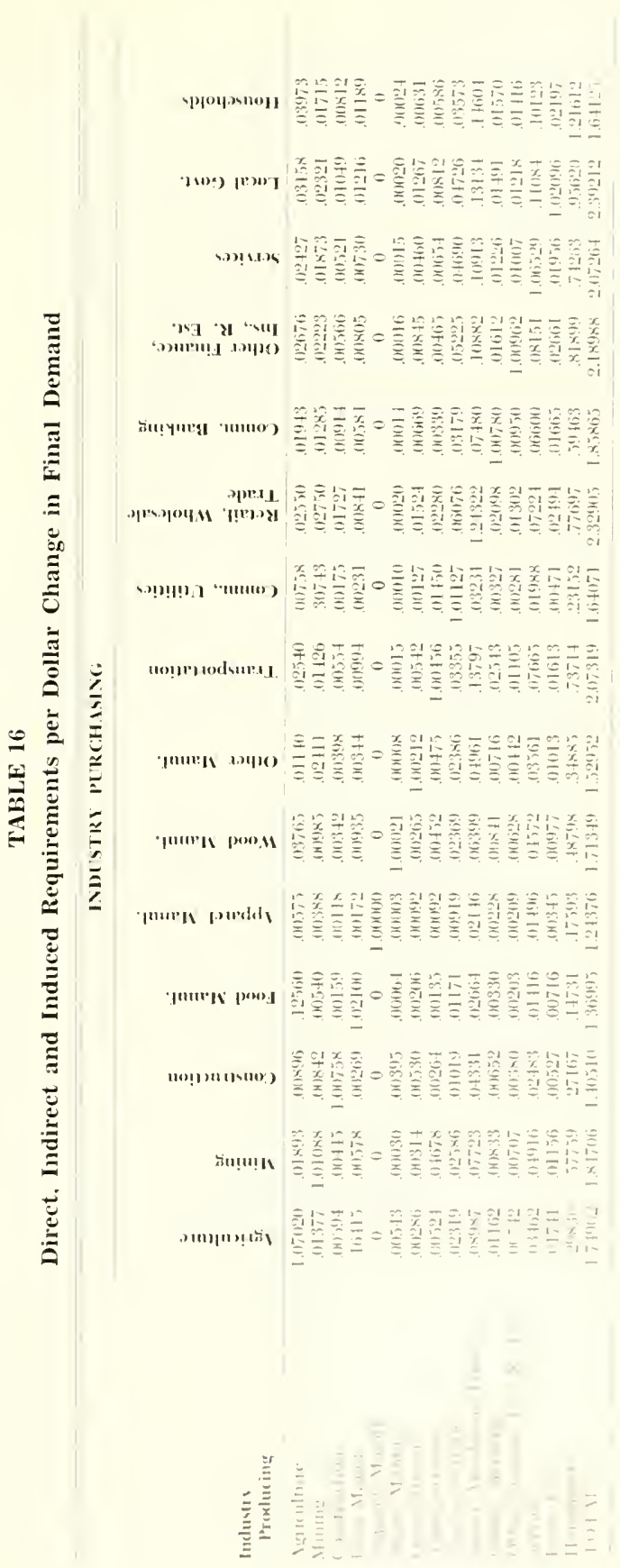


final demand for the services and products of wood manufacturing generates a total of $\$ 1.71$ in the local economy.

\section{Input-Output Multipliers}

A regional input-output transactions table and the relationships derived therefrom provide information on the degree of interdependence within the region. A number of multipliers can be developed from available data. This study will be confined to the consideration of only income and employment multipliers.

\section{INCOME MULTIPLIERS}

The transactions table depicts the interdependency of local households in the local economy. With respect to industrial output, the table estimates the magnitude of sales of goods and services to local households by each enclogenous sector. In addition, payments to local households by each endogenous sector in the form of wages, salaries, property income, dividends, etc., are systematically quantified.

The table of direct requirements coefficients (Table 13) and the results of each matrix inversion (Tables 14 and 16) can be used to analyze the impact of changes in final demand on local household income. Total changes in household income per unit change in final demand for output originating in each of the 14 endogenous sectors can be broken down into three components: (1) direct, (2) indirect, and (3) induced changes.

The direct component represents an estimate of the initial impact on household income per mit change in final demand. Direct changes in household payments result from a particular sector's immediate response to a change in final demand. Indirect changes arise out of output adjustments by all enclogenous scetors necessary to directly and inclirectly support the change in deliveries tis final demand. Induced changes in how thin pavments result from changes in pruchases of locally produced goods

and indircet requirein final demand requirlocal consumption ex-
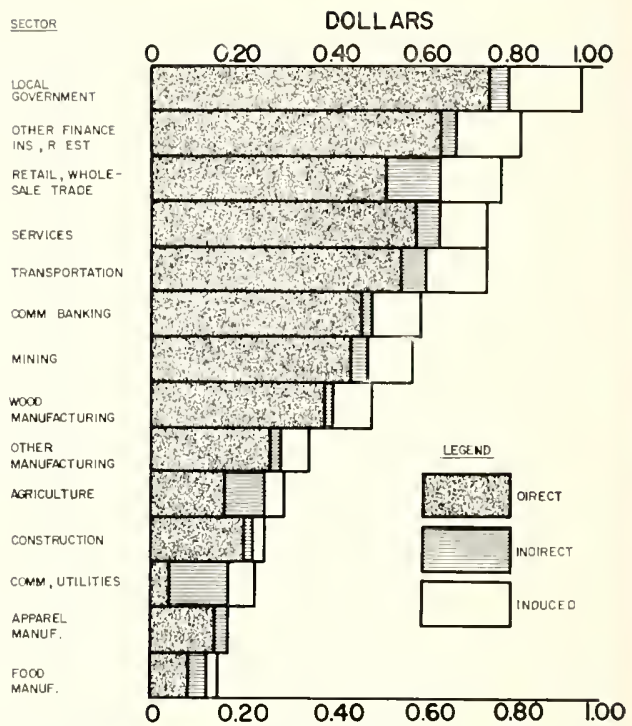

FIGURE \%. Direct, Indirect, and Induced Changes in Household Income per Dollar Change in Final Demand

penditures remain at the same level despite a postulated change in household income generated by a change in final demand." Inclusion of the household sector as an endogenous sector in the transaction table is explicit recognition of the fact that a change in household receipts initiates a change in the level of local household expenditures. This change in household expenditures results in adjustments in output in the endogenous sectors and further changes in payments to local households. This change in payments to local households resulting from sectoral adjustments to an initial change in the level of local household expenditures is referred to as an induced change in household payments.

Figure 7 presents a graphic summary of the clirect, indirect and induced changes in local household payments associated with a change in final demand for each endogenous sector. These estimates were obtained in the following manner: 
(1) Direct changes in houschold income were obtained from the household row in Table 13.

(2) Indirect changes in household income per unit change in final demand were computed as follows:

a. Each column entry in the matrix of direct and indirect requirements (Table 14) was multiplied by the corresponding household row entry in the matrix of direct requirements for the industry named at the left.

b. The column sums of the above computations were computed and the sum of the direct household requirements was subtracted from it.

(3) Subtraction of the direct and indirect household income changes from the household row of the matrix in Table 16 leaves the induced change presented in Figure 7.

Two types of household income multipliers were calculated. The Type I multiplier is an estimate of the direct and indirect change in household income per dollar change in direct payments to households by sector. The Type II multiplier includes the induced, as well as direct and indirect changes in household income as a result of a dollar change in direct payments to households. Type I and II multipliers for the Upper South Branch economy are presented in Table 17. Table 17 shows that a dollar change in household payments, as the result of a change in final demand for output originating in agriculture, is estimated to directly and indirectly generate a total of $\$ 1.50$ in local household payments. When induced output changes are included, the estimate is $\$ 1.82$. In every case, the Type II multiplier is larger than its Type I counterpart. This is because new rounds of household expenditures are generated within the local economy as a result of a change in final demand for output originating in any one of the endogenous sectors.

The indirect and induced changes in household income per unit change in direct household payments for endogenous sectors are presented in Figure 8. The relative sizes of the Type $I$ and II income multiplicrs can be secn. The induecd component is the difference between the two multipliers. These data accentuate the degrec of interdependency within sectors of the local economy. Sectors which purchased relatively large portions of their non-labor inputs from other endogenous sectors had higher indirect and induced change in household income.

Caution should be used in interpreting and using the income multipliers. As is shown in Table 17, in general, there is a negative relationship between the total effect of a change in output on household payments and the size of the income multipliers. For example, a dollar change in output by the local government sector will generate a total of 95 cents additional payments to households, but the income multipliers are relatively low due to the fact that a large per cent of the total change in household payments is a direct change and very little additional activity is generated. In contrast, a dollar change in the output of the communications and utilities sector generates only 23.5 cents additional payments to households, but the income multipliers are relatively much higher because a higher per cent of the payments is indirect and induced. The income multipliers reflect the impact of changes in income - not changes in output.

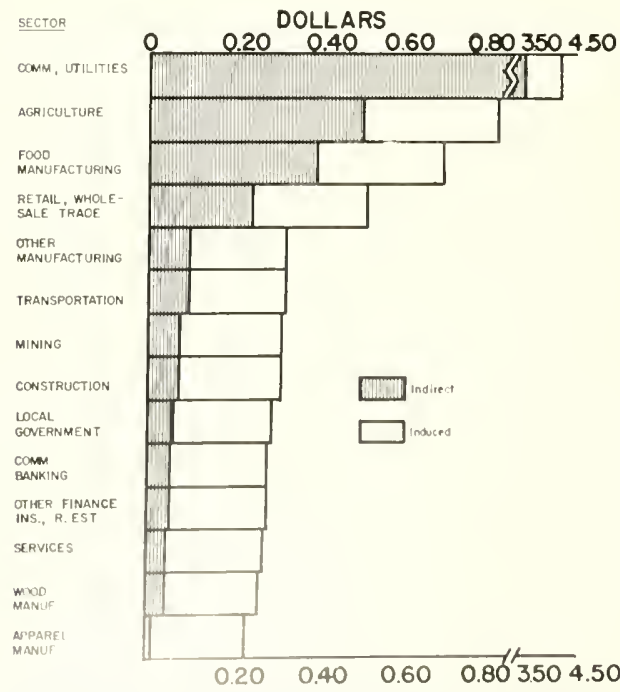

Fistigles 8 . Indirect and Induced llousehold Inceme (remerated as a liesult of One Dollall Change in Dipect Houschold P'alyments 
The implications of the income multipliers presented above can be illustrated by the use of an example in which a $\$ 100.000$ increase in deliveries to final demand (exports for example) is assumed (Table 18). If this increase were realized in the agricultural sector of the local economy (while the level of final demand in all remaining sectors remained constant, the direct change in household income would be $\$ 16,351$. However, increased output indirectly required from other endogenous sector's of the local economy to support this increase in final demand for agricultural products is estimated to increase total payments to local households by the extent of the Type I income multiplier for the agricultural sector (1.50). Therefore, a direct increase in household income due to an increase of $\$ 100,000$ in final demand for agricultural goods and services is estimated to directly and indirectly generate a total of $\$ 24.526$ ( $\$ 16351 \times 1.50)$ in household payments. If output adjustments arising from additional rounds of endogenous household consumption expenditures are included, a direct income change of $\$ 16,351$ will generate an estimated $\$ 29,759(\$ 16,351 \times 1.82)$ in household payments.

Examination of a sector such as apparel manufacturing which has relatively weak structural ties with other local industrial sectors, i. e., most non-labor inputs are purchased outside the area, shows that a $\$ 100,000$ increase in exports would directly increase household income by $\$ 14,324$. Household income would be indirectly increased by $\$ 143 \quad$ (\$14467 $\$ 14324$ ) and induced changes would increase total household income to $\$ 17.618(\$ 14,324 \mathrm{x}$ $1.23)$.

The communications and utilities sector has a relatively low direct household coefficient, i.e., a $\$ 100,000$ increase in exports adds less than $\$ 4500$ in direct local household payments. However, the structural relationships with other endogenous sectors are sufficiently strong so that a $\$ 100,000$ increase in final demand directly

TABLE 17

Ilousehold Income Multipliers by Industrial Sector

\begin{tabular}{|c|c|c|c|c|c|}
\hline \multirow[b]{3}{*}{ Sector } & \multicolumn{3}{|c|}{ Dollars } & \multirow{2}{*}{\multicolumn{2}{|c|}{ Income Multipliers }} \\
\hline & \multirow{2}{*}{$\begin{array}{l}\text { Direct } \\
\text { Change' } \\
\text { (A) }\end{array}$} & \multirow{2}{*}{$\begin{array}{c}\text { Direct, } \\
\text { Indirect } \\
\text { Change } \\
\text { (B) }\end{array}$} & \multirow{2}{*}{$\begin{array}{c}\text { Direet, } \\
\text { Indirect, } \\
\text { Induced } \\
\text { Change } \\
\text { (C) }\end{array}$} & & \\
\hline & & & & $\begin{array}{r}\text { Type I' } \\
\text { (D) }\end{array}$ & $\begin{array}{c}\text { Type II } \\
\text { (E) }\end{array}$ \\
\hline Agriculture & .16351 & .24532 & .29830 & 1.50 & 1.82 \\
\hline Vining & .44242 & .47494 & .57759 & 1.07 & 1.31 \\
\hline Construction & .20788 & .22336 & .27167 & 1.07 & 1.31 \\
\hline Food Manufacturing & .08689 & .12114 & .14731 & 1.39 & 1.69 \\
\hline Apparel Manufacturing & .14324 & .14466 & .17593 & 1.01 & 1.23 \\
\hline Wood Manufacturing & .38642 & .40126 & .48798 & 1.04 & 1.26 \\
\hline Other Manufacturing & .26346 & .28684 & .34885 & 1.09 & 1.32 \\
\hline Transportation & .55677 & .60615 & .73714 & 1.09 & 1.32 \\
\hline Communications, Utilities & .04479 & .19037 & .23512 & 4.25 & 5.17 \\
\hline Retail Wholesale Trade & .51611 & .63889 & .77697 & 1.24 & 1.51 \\
\hline ('rmturetal Banking & .46651 & .48896 & .59463 & 1.05 & 1.28 \\
\hline 1.the i y mef. Insurance, & & 67348 & 81899 & 1.05 & 1.28 \\
\hline & .58491 & .61064 & .74263 & 1.04 & 1.27 \\
\hline$H_{1}+r_{i}+\ldots-\ldots+$ & .74454 & .78628 & .95620 & 1.06 & 1.29 \\
\hline
\end{tabular}

change in housebulel income per dollar thange in output.

the direce houvehold coefficint household iow, Fable l3) for the industs named

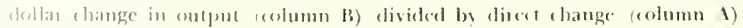
incerme foctumen () divisted by disect dhange (column 1) 
TABLE 18

Change in Total Ilousehold Ineome Resulting From a \$100,000 Change in Output by Sector

\begin{tabular}{|c|c|c|c|c|c|c|}
\hline Sector & $\begin{array}{l}\text { Change } \\
\text { in } \\
\text { Output }\end{array}$ & $\begin{array}{c}\text { Direct } \\
\text { Change } \\
\text { In llouse- } \\
\text { hold In- } \\
\text { come' }\end{array}$ & $\begin{array}{l}\text { Type I } \\
\text { Miulti- } \\
\text { plier }\end{array}$ & $\begin{array}{l}\text { Direet } \\
\text { and In- } \\
\text { direet } \\
\text { Change }\end{array}$ & $\begin{array}{c}\text { Type } \\
\text { II } \\
\text { Multi- } \\
\text { plier }\end{array}$ & $\begin{array}{l}\text { Direet. } \\
\text { Indirect } \\
\text { Induced } \\
\text { Change' }\end{array}$ \\
\hline Agriculture & $\$ 100000$ & $\$ 16,351$ & 1.50 & $\$ 24,526$ & 1.82 & $\$ 29,759$ \\
\hline Mining & 100000 & 44,242 & 1.07 & 47339 & 1.31 & 57,957 \\
\hline Construction & 100000 & 20,788 & 1.07 & 22.243 & 1.31 & 27,232 \\
\hline Food Manuf. & 100,000 & 8,689 & 1.39 & 12,078 & 1.69 & 14,684 \\
\hline Apparel Manuf. & 100,000 & 14,324 & 1.01 & 14,467 & 1.23 & 17,618 \\
\hline Wood Manuf. & 100.000 & 38,642 & 1.04 & 40,188 & 1.26 & 48689 \\
\hline Other Manuf. & 100,000 & 26.346 & 1.09 & 28,815 & 1.32 & 34896 \\
\hline Transportation & 100000 & 55,677 & 1.09 & 60.687 & 1.32 & 73,494 \\
\hline $\begin{array}{l}\text { Communications, } \\
\text { Utilities } \\
\text { Retail, Wholesale }\end{array}$ & 100,000 & 4,479 & 4.25 & 19,036 & 5.17 & 23,156 \\
\hline Trade & 100,000 & 51,611 & 1.24 & 63,998 & 1.51 & 77,933 \\
\hline $\begin{array}{l}\text { Commercial Banking } \\
\text { Other Finance, } \\
\text { Insurance, Real }\end{array}$ & 100000 & 46,651 & 1.05 & 48,983 & 1.28 & 59,713 \\
\hline Estate & 100,000 & 64,127 & 1.05 & 67.933 & 1.28 & 82,082 \\
\hline Services & 100000 & 58,491 & 1.04 & 60.831 & I. 27 & 74,283 \\
\hline Local Government & 100,000 & 74,454 & 1.06 & 78.921 & 1.29 & 96.046 \\
\hline
\end{tabular}

and indirectly yields an estimated $\$ 19,036$ $(\$ 4.479 \times 4.25)$ in total household payments. Allowance for induced changes in household income increases this estimate to $\$ 23,156(\$ 4.479$ $x$ 5.17). Thus, both the size of direet changes in household income by industrial sector and the degree of struetural interdependency are important in evaluating the impact on the level of household income of changes in deliverios to final demand by industrial sectors in the local economy.

Table 19 illustrates the impact on local household income of a change in final demand for the goods and services produced by each of the 14 industrial sectors in the Upper South Branch transactions table. Output is assumed to be cxpanded to the extent that direct houschold payments are increased by $\$ 100,000$. Due to variation in the magnitude of direct houschold payments as a per cent of gross output, increases in deliveries to final demand which are required to realize a $\$ 100,000$ direct change in local household payments are estimated to vary from $\$ 134,000$ (local govermment) 10 $\$ 2.232,600$ (communications and utilities). Further, a comparable direct change in houschold payments $(\$ 100,000)$ would require sectoral output to be expanded by only 2.51 per cent of 1965 total gross output in the wholesale and retail trade sector but by more than 31 per eent in the other finance, insurance, and real estate sector. Type I and II ineome multipliers indicate the magnitude of inclirect of indirect plus indueed changes in houschold income which are associated with the $\$ 100,000$ direct change in sectoral ineome (Table 19).

The masnitude of deliveries to final demand

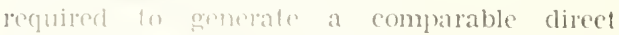
change in itrome and employment as well as the size on serdofal multipliers must be consideroc in ereth ring the growth potential of an industriat sector A neetor such as agrieulture has 
a relatively luigh multiplier. Moreover, sizable indirect and induced benefits indicated by this multiplier can be realized from a small increase in final demand for agricultural products (relative to current levels of gross output). The communications and utilities sector also shows a large income multiplier (Type I $=4.25$, Type II $=5.17$ ) but direct changes in household income require a large expansion of output relative to current (1965) levels. An analogous evaluation can be made for all other industrial sectors in Table 19.

\section{Employment Multipliers}

The employment effects of a change in demand are often as important as the income effects, and changes in employment have an impact on income. Therefore, the effects on employment of a change in final demand for the output of each endogenous sector were estimated.
Changes in employment resulting from changes in final demand depend upon each endogenous sector's employment function. 'The assumption was made that each endogenous sector exhibits a linear and homogenous employment function.

The estimated employment in each endogenous sector was divided by the sector's total gross output to obtain a ratio expressing employment per thousand dollars of total gross output. This ratio was then used to compute the direct change in employment associated with an increase or decrease in deliveries to final demand for each endogenous sector. The following procedure was used to estimate the indirect and induced employment effects associated with a unit change in final demand:

1. Each column entry in the matrix of direct and indirect requirements (Table 14) was multiplied by the direct employment ratio for the industry named at the left.

2. The column sum of the above computa-

TABLE 19

Direct Change Required in Gross Ontput by Sector to Obtain a $\$ 100,000$ Direct Change in IIousehold I'ayments and the Impact of a $\$ 100,000$ Change in Household Payments on Total Household Income

\begin{tabular}{|c|c|c|c|c|c|c|c|}
\hline \multirow{4}{*}{ Sector } & \multirow{3}{*}{\multicolumn{2}{|c|}{$\begin{array}{c}\text { Direct Change } \\
\text { Required In } \\
\text { Gross } \\
\text { Output }\end{array}$}} & \multirow{4}{*}{$\begin{array}{l}\text { Direct } \\
\text { Income } \\
\text { Change } \\
(000)\end{array}$} & \multirow{4}{*}{\multicolumn{2}{|c|}{ 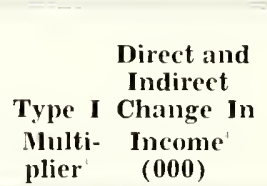 }} & \multirow{4}{*}{\multicolumn{2}{|c|}{$\begin{array}{c}\text { Direct, } \\
\text { Indirect, } \\
\text { and Induced } \\
\text { Type II Change } \\
\text { Multi- in Income } \\
\text { plier }(000)\end{array}$}} \\
\hline & & & & & & & \\
\hline & & & & & & & \\
\hline & $\begin{array}{l}\text { Total } \\
(000)\end{array}$ & l'er Cent & & & & & \\
\hline Agriculture & $\$ 611.6$ & 3.18 & $\$ 100.0$ & 1.50 & $\$ 150.0$ & 1.82 & 182.0 \\
\hline Mining & 226.0 & 2.82 & 100.0 & 1.07 & 107.0 & 1.31 & 131.0 \\
\hline Construction & 481.0 & 4.14 & 100.0 & 1.07 & 107.0 & 1.31 & 131.0 \\
\hline Focú Manuf. & $1,150.9$ & 13.85 & 100.0 & 1.39 & 139.0 & 1.69 & 169.0 \\
\hline Apparel Manuf. & 698.1 & 30.49 & 100.0 & 1.01 & 101.0 & 1.23 & 123.0 \\
\hline Wood Manuf. & 258.8 & 6.53 & 100.0 & 1.04 & 104.0 & 1.26 & 126.0 \\
\hline Other Manuf. & 379.6 & 23.16 & 100.0 & 1.09 & 109.0 & 1.32 & 132.0 \\
\hline Transportation & 179.6 & 11.45 & 100.0 & 1.09 & 109.0 & 1.32 & 132.0 \\
\hline Comm, Utilities & $2,232.6$ & 21.77 & 100.0 & 4.25 & 425.0 & 5.17 & 517.0 \\
\hline Wholesale, Retail & & & & & & & \\
\hline Trade & 193.8 & 2.51 & 100.0 & 1.24 & 124.0 & 1.51 & 151.0 \\
\hline $\begin{array}{l}\text { (* Pdrking } \\
\therefore+\text { r. in aner In: }\end{array}$ & 214.4 & 22.64 & 100.0 & 1.05 & 105.0 & 1.28 & 128.0 \\
\hline is & 155.9 & 31.01 & 100.0 & 1.05 & 105.0 & 1.28 & 128.0 \\
\hline & 171.0 & 4.64 & 100.0 & 1.04 & 104.0 & $\begin{array}{l}1.20 \\
1.27\end{array}$ & $\begin{array}{l}120.0 \\
127.0\end{array}$ \\
\hline & 134.3 & 5.90 & 100.0 & 1.06 & 106.0 & 1.29 & 129.0 \\
\hline
\end{tabular}


tion represents the direct and indirect employment requirements per thousand dollar change in final demand.

3. The above computations were also performed on the matrix of direct, indirect, and induced requirements to generate an estimate of direct, indirect, and induced employment requirements per thousand dollars change in final demand.

The total effect of a change in final demand on employment within the local community can be broken down into three components: (1) direct employment changes which result from a specific sector's response to a change in final demand, (2) indirect employment changes which result from endogenous output adjustments required to directly and indirectly support a change in deliveries to final demand, and (3) induced employment changes arising out of sectoral responses to a change in the level of local household consumption expenditures.

The ratio of direct to the sum of direct and indirect changes in employment is a Type I employment multiplier. The ratio of direct to the sum of direct, indirect, and induced changes in employment is a Type II employment multiplier. These two types of multipliers are analogous to income multipliers developed previously. Type I and Type II multipliers for each endogenous sector are presented in Table 20. Each multiplier permits a comparison of the iotal generative effect on local employment resulting from a unit direct change in employment. For example, a one unit direct change in agricultural employment is estimated to directly and indirectly create 1.27 units of employment. Inclusion of the induced component, i.e., the effect of increased household consumption demand, increases the multiplier to 1.39 (Table 20). Once again, relatively high employment multipliers indicate greater structural interdependence with respect to local input purchases while low multipliers are indicative of relatively weak linkages between endogenous sectors of the model.

TABLE 20

Estimated Changes in Employment Resulting From a $\$ 1,000$ Change in Output and Type I and Type II Employment Multiplier by Sector

\begin{tabular}{|c|c|c|c|c|c|}
\hline \multirow[t]{2}{*}{ Sector } & \multirow{2}{*}{$\begin{array}{c}\text { Direct } \\
\text { Change }\end{array}$} & \multirow{2}{*}{$\begin{array}{l}\text { Dircet, } \\
\text { Indireet } \\
\text { Chatuge }\end{array}$} & \multirow{2}{*}{$\begin{array}{l}\text { Dircet. } \\
\text { Indirect, } \\
\text { Induced } \\
\text { Change }\end{array}$} & \multicolumn{2}{|c|}{$\begin{array}{l}\text { Employment } \\
\text { Multiplier }\end{array}$} \\
\hline & & & & Type I' & Type II \\
\hline Agriculture & .11057 & .14049 & .15402 & 1.27 & 1.39 \\
\hline Mining & .06739 & .07574 & .10200 & 1.12 & 1.51 \\
\hline Construction & .02583 & .02975 & .04210 & 1.15 & 1.63 \\
\hline Food Manufacturing & .04283 & .06047 & .06716 & 1.41 & 1.56 \\
\hline Apparel Manufacturing & .07907 & .07936 & .08736 & 1.00 & 1.10 \\
\hline Wood Manufacturing & .10955 & .11479 & .13697 & 1.05 & 1.25 \\
\hline Other Manufacturing & .07323 & .07839 & .09424 & 1.07 & 1.29 \\
\hline Transportation & .13267 & .14635 & .17987 & 1.10 & 1.36 \\
\hline Communications, Utilities & .00799 & .03146 & .04197 & 3.94 & 5.25 \\
\hline Retail, Wholesale Trade & .18356 & .22029 & .25562 & 1,20 & 1.39 \\
\hline Commercial Banking & .04755 & .05278 & .07982 & 1.11 & 1.68 \\
\hline \multicolumn{6}{|l|}{ Other Finance, Insurance, } \\
\hline Real Estate & .07959 & .08738 & .12461 & 1.10 & 1.57 \\
\hline Services & .14255 & .14936 & $.18: 313$ & 1.05 & 1.28 \\
\hline Local Government & 19779 & .20831 & $4 !(1) 3$ & 1.05 & 1.26 \\
\hline
\end{tabular}




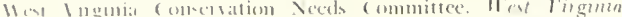

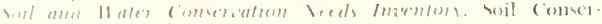

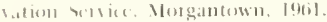

II

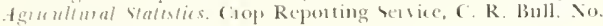

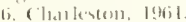

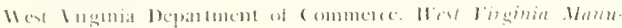

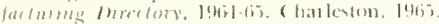

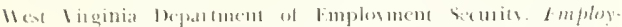

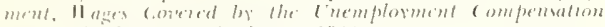

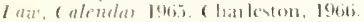

IItnk force. Emplovment. Cimmplovment, 1958. 196;. Rל Seldes ]o6, Vol. I and 11, Chateston, 1966.
West linginia Department of Mlumes. 1965 Anmul liepont of the

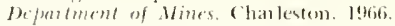

Hest Sirginia Depantment ol Mutor Vehieles. Scludule of Motor reliche Fees for all Clasws. (harleston, 1960.

Nien linginia Insurance Commission. Insurance Commissioner's

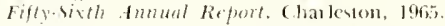

Went Virginia legislative inditor's office, Disest of Revenues in llest Tirginia. (harkston, 1962.

Wen lirginia state superintendent of free selools, Fiff-second Immol Refort. statistical amd financial Report, Vol. II, Charlostom, 1966

llest Vinginia Iax Commission. Thitemeh Biennial Report. Charlesun, 1965. 



